NBER WORKING PAPER SERIES

\title{
DOES OPENNESS TO TRADE MAKE COUNTRIES MORE VULNERABLE TO SUDDEN STOPS, OR LESS? USING GRAVITY TO ESTABLISH CAUSALITY
}

\author{
Jeffrey A. Frankel \\ Eduardo A. Cavallo \\ Working Paper 10957 \\ http://www.nber.org/papers/w10957
NATIONAL BUREAU OF ECONOMIC RESEARCH
1050 Massachusetts Avenue
Cambridge, MA 02138 \\ December 2004
}

The views expressed herein are those of the author(s) and do not necessarily reflect the views of the National Bureau of Economic Research.

(C) 2004 by Jeffrey A. Frankel and Eduardo A. Cavallo. All rights reserved. Short sections of text, not to exceed two paragraphs, may be quoted without explicit permission provided that full credit, including (C) notice, is given to the source. 
Does Openness to Trade Make Countries Mor Vulnerable to Sudden Stops or Less? Using Gravity to Establish Causality

Jeffrey A. Frankel and Eduardo A. Cavallo

NBER Working Paper No. 10957

December 2004

JEL No. F32, F36, F41

\begin{abstract}
Openness to trade is one factor that has been identified as determining whether a country is prone to sudden stops in capital inflow, currency crashes, or severe recessions. Some believe that openness raises vulnerability to foreign shocks, while others believe that it makes adjustment to crises less painful. Several authors have offered empirical evidence that having a large tradable sector reduces the contraction necessary to adjust to a given cut-off in funding. This would help explain lower vulnerability to crises in Asia than in Latin America. Such studies may, however, be subject to the problem that trade is endogenous. We use the gravity instrument for trade openness, which is constructed from geographical determinants of bilateral trade. We find that openness indeed makes countries less vulnerable, both to severe sudden stops and currency crashes, and that the relationship is even stronger when correcting for the endogeneity of trade.
\end{abstract}

Jeffrey A. Frankel

Kennedy School of Government

Harvard University

79 JFK Street

Cambridge, MA 02138-5801

and NBER

jeffrey_frankel@harvard.edu

Eduardo A. Cavallo

Kennedy School of Government

Harvard University

79 JFK Street

Cambridge, MA 02138-5801

eduardo_cavallo@ksg.harvard.edu 


\section{Does Openness to Trade Make Countries More Vulnerable to Sudden Stops, Or Less? Using Gravity to Establish Causality}

A "sudden stop" -- and abrupt cut-off in capital inflows -- entails a resource transfer to creditor countries, from the debtor country. Often it also entails a financial or currency crisis in the latter, accompanied by a sharp fall in output. ${ }^{3}$ Broadly speaking, there are two opposing views on the relationship between a country's openness and whether it is prone to sudden stops. The first view is that openness makes a country more vulnerable to sudden stops. A country highly integrated into world markets is more exposed to shocks coming from abroad. The second view is that countries that are open to international trade are less vulnerable to sudden stops. If the ratio of trade to GDP is structurally high, it is easier to adjust to a cut-off in international financing of a given magnitude. This paper tests the relationship between trade openness and vulnerability to sudden stops to help choose between the two hypotheses. Such tests have been done before, but without fully taking into account the possible endogeneity of trade. Our incremental contribution here is to use the gravity instrument for trade openness -- which aggregates geographically-determined bilateral trade across a country's partners -- to correct for the possible endogeneity of trade.

The view that openness makes countries more vulnerable to crises comes in a number of forms. The claim is particularly salient if we are talking about openness to capital flows: “you can't have an international debt crisis if you don't have international debt. ${ }^{4}$ But the claim is also made with respect to openness to trade. One variant is that a weakening in a country's export markets is sometimes the trigger for a sudden stop in capital flows, so that a high-trade country is more vulnerable. Another variant notes that sudden stops in finance often extend to a loss in trade credit -- especially for imports, but sometimes also even for exports -- and that the resulting shrinkage in trade is more painful if trade was a larger share of the economy. A third variant says that openness to trade in practice goes hand in hand with openness to financial flows, for example because much trade needs multinational corporations, who in turn need to be able to move money across

\footnotetext{
3 To the best of our knowledge, the expression "Sudden Stops" was first used by Dornbusch, Goldfajn and Valdes (1995) and has since become increasingly popular. The first analytic approach to the problem of sudden stops is Calvo (1998).

${ }^{4}$ Even here, the evidence is mixed. A good entry point to the large literature on financial liberalization and economic performance is Prasad, Rogoff, Wei, and Kose (2003).
} 
national borders; or because it is harder to enforce capital controls if trade is free. ${ }^{5}$ In the limiting case, a country that is in autarky with respect to trade must have a net capital account of zero due to the balance of payments adding up constraint. Regardless the specific reasoning, the notion that globalization leads to crises is a generalization that appeals to many.

The view that openness to trade makes countries less vulnerable also comes with a number of different specific mechanisms that have been proposed. Rose (2002) argues that the threatened penalty of lost trade is precisely the answer to the riddle "why do countries so seldom default on their international debts?" and offers empirical evidence that strong trade links are correlated with low default probabilities. International investors will be less likely to pull out of a country with a high trade/GDP ratio, because they know the country is less likely to default. A higher ratio of trade is a form of "giving hostages" that makes a cut off of lending less likely. ${ }^{6}$

Another variant of the argument that openness reduces vulnerability takes as the relevant penalty in a crisis the domestic cost of adjustment, i.e., the difficulty of eliminating a newly-unfinanceable trade deficit. The argument goes back at least to Sachs (1985). He suggested that Asian countries had been less vulnerable to debt crises than Latin American countries -- despite similar debt/GDP ratios -- because they had higher export/GDP ratios. The relatively worse performance observed in Latin America was due to the lower availability of export revenue to service debt. He concludes that: "After a decade of rapid foreign borrowing, too many of Latin America's resources were in the nonexporting sector, or abroad. When financial squeeze in the early 1980's caused banks to draw their loans, the only way that Latin countries could maintain debt servicing was through a recession and a large reduction in imports combined with debt rescheduling” (p.548). More recently, Guidotti et. al. (2004) make a similar point by providing evidence that economies that trade more recover fairly quickly from the output contraction that usually comes with the sudden stop, while countries that are more closed suffer sharper output contraction and a slower recovery.

\footnotetext{
${ }^{5}$ Aizenman (2003), and Aizenman and Noy (2004).

${ }^{6}$ The point was originally made by Eaton and Gersovitz (1981). They argue that countries that trade more are subject to more harmful trade-related retaliation in the aftermath of default and therefore are less likely to default.
} 
Consider first a country that faces a given cut-off in financing, and must adjust without nominal or real exchange rate flexibility. The adjustment must then come through a reduction in spending. To achieve a $\$ 1$ billion improvement in the trade balance, the contraction has to be $\$(1 / m)$ billion, where $m$ is defined as the marginal propensity to import (in a Keynesian model) or the share of spending that falls on tradable goods (in a tradable/nontradable model). The lower is $m$, the more painful the adjustment. Whether output itself falls depends, of course, primarily on whether wages and prices are flexible. But even in a full-employment world, sharp reductions in consumption are painful.

Consider, second, a country that does have the option of nominal and real exchange rate flexibility. In traditional textbook models, if the adjustment is achieved in part through nominal and real depreciation, rather than exclusively through expenditure-reduction, the country can accommodate the tougher new financing constraint without necessarily suffering a recession. This is true even if a relatively large devaluation is required to generate the necessary improvement in the trade balance. But since the emerging market crises of 1994-1998, economists have increasingly emphasized contractionary effects of devaluation, particularly via the balance sheet effect: if the country's debts are denominated in foreign currency, the balance sheets of the indebted banks and corporations are hit in proportion to the devaluation. ${ }^{7}$ If the economy is starting from a high ratio of trade to GDP the necessary devaluation need not be large, and therefore the adverse balance sheet effect need not be large. But if the economy is not very open to trade to begin with, the necessary devaluation, and the resulting balance sheet impact and recession, will all be large. Again we arrive at the result that whether the necessary adjustment will be large and painful depends inversely on openness.

The balance sheet version of the openness story is modeled formally by Calvo, Izquierdo, and Talvi (2003) and Cavallo (2004). Both have in mind the example of Argentina, which has traditionally had a low ratio of trade to GDP, and has suffered some

\footnotetext{
7 The analytical literature on balance sheet effects and output contraction includes: Kiyotaki and Moore (1997), Krugman (1999), Aghion, Banerjee and Bacchetta (2000), Cespedes, Chang and Velasco (2000, 2003), Chang and Velasco (1999), Caballero and Krishnamurty (2002), Christiano, Gust and Roldos (2002), Dornbusch (2001), and Mendoza (2002). Cavallo, Kisselev, Perri and Roubini (2002) provide empirical evidence of the output cost associated to the balance sheet effect. Looking at the experience of the 1990's they show that countries entering a crisis with high levels of foreign debt tend to experience large real exchange rate overshooting (devaluation in addition to the long run equilibrium level) and large output contractions.
} 
of the worst sudden stops. ${ }^{8}$ But the hypothesis that openness to trade reduces a country's vulnerability to sudden stops transcends any one formal model, causal link, or country example. The same is true of the hypothesis that openness raises a country's vulnerability. This paper seeks to choose empirically between the two competing hypotheses.

What do we mean by "vulnerability to sudden stops?" Our primary criterion will be a probit model measuring the probability of a sudden reduction in the magnitude of net capital inflows, following closely the definition of Calvo, Izquierdo and Mejia (2003). But we also consider some other possible definitions. We look at the definition of crisis episodes in Frankel and Rose (1996) and Frankel and Wei (2004), which is based on the exchange market pressure variable defined as the percentage depreciation plus percentage loss in foreign exchange reserves. In addition to looking at the probability of a sudden stop or currency crisis, we also examine the subsequent output loss and its magnitude. One possibility is that in a country where sudden stops are associated with large recessions, they are more likely to occur, because investors fear that the country will default to avoid the recessions -- Cavallo (2004). ${ }^{9}$ The opposite relationship between the magnitude and probability of crises is also possible, however. Dooley (2000) has suggested that when crises lead to recessions, countries are more likely to take care to avoid them, and so sudden stops are less likely.

Calvo, Izquierdo and Mejia (2003) and Edwards (2004) are among the empirical papers that find that openness to trade is associated with fewer sudden stops. On the other hand, Milesi-Ferretti and Razin $(1998,2000)$ find that openness helps trigger crises and/or

Similarly, Guidotti, Sturzenneger and Villar (2003) find evidence that liability dollarization worsen output recovery after a sudden stop in capital inflows.

${ }^{8}$ Others who have argued that Argentina's low trade/GDP ratio helps explain why it was such a victim of the global sudden stop after 1999 include Calvo, Izquierdo, and Mejia (2003), Calvo and Talvi (2004), Desai and Mitra (2004) and Treasury Secretary Paul O'Neill, who once said it was unsurprising the Argentines had lost the confidence of investors because they don't export anything.

${ }^{9}$ Cavallo's model shows first that under a plausible set of assumptions applicable to emerging market economies, closedness is costly in terms of output loss in the aftermath of sudden stops. The reason is that these shocks trigger real exchange rate depreciations and these, in turn, are contractionary in economies that are highly dollarized. The size of the contraction (or, analogously, the "cost of the adjustment") is negatively related to the degree of trade openness. It also shows that foreign investors who foresee this are more likely to pull their money out of these countries, making sudden stops more likely. 
sharp reversals of the current account. ${ }^{10}$ All these papers -- except the first -- use the trade/GDP ratio as the measure for openness to trade. ${ }^{11}$

A critic might argue that the trade/GDP ratio is endogenous. One way in which trade openness could be endogenous is via income: richer countries tend to liberalize trade barriers -- in part because their mode of public finance shifts from tariff revenue to income or VAT taxes. A second way is that trade liberalization could be part of a more general reform strategy driven by pro-globalization philosophy or "Washington Consensus" forces. Other aspects of such a reform program, such as privatization, financial liberalization, or macroeconomic stabilization might affect the probability of crises, and yet an OLS regression analysis might inappropriately attribute the effect to trade. A third way that trade openness could be endogenous is that experience with crises -- the dependent variable -may itself cause liberalization, via an IMF program. Or it might have the opposite effect, if a country's response to a crash is disenchantment with globalization and the Washington Consensus.

A fourth way in which trade openness could be endogenous is through the feedbacks between trade and financial openness. Aizenman (2003) shows in the setting of a simple model how more commercial openness increases the effective cost of enforcing financial repression, rendering financial openness a by-product of greater trade integration. Similarly, one could potentially think of a reverse causality process, whereby for example, greater financial openness may reduce the cost of trade credit and encourage FDI, and both adjustments may facilitate more commercial trade. Aizenman and Noy (2004) empirically investigate the presence of two-way feedbacks between financial and trade integration.

How can the endogeneity of trade be addressed $?^{12}$ We use gravity estimates to construct an instrumental variable for trade openness. This methodology was developed by Frankel and Romer (1999) in the context of the effect of trade on growth, and was later applied to a variety of settings in which trade and some other variable could potentially be

\footnotetext{
${ }^{10}$ Along with current account balance, terms of trade, world interest rates and other variables. Easterly, Islam and Stiglitz (2001) find that trade openness raises output volatility.

${ }^{11}$ Calvo, Izquierdo and Mejia (2003) use a different measure of openness, which they claim to be superior to the trade to GDP ratio because it is not subject to direct valuation effects that occur as a result of changes in the real exchange rate. They use $\mathrm{w}=\left(\mathrm{Y}^{*}-\mathrm{S}\right) / \mathrm{A}^{*}$, where $\mathrm{Y}^{*}$ is the supply of tradable goods, $\mathrm{S}$ are factor payments and $\mathrm{A}^{*}$ is the absorption of tradable goods.
} 
jointly determined. ${ }^{13}$ Basically, it consists of aggregating up across a country's partners the prediction of a gravity equation that explains trade with distance, population, language, land-border, land-area, and landlocked status. Gravity estimates are a good instrumental variable, because they are based on geographical variables which are plausibly exogenous and yet when aggregated across all bilateral trading partners are highly correlated with a country's overall trade.

In this paper we use capital account (also known as financial account) and current account data for all countries in the world with data available from the IMF International Financial Statistics (IFS), to identify sudden stops in capital flows statistically. The data set covers 141 countries in total, for the period 1970-2002. Following Calvo, Izquierdo, and Mejia (2003), we define a sudden stop episode as taking place in a country during the year in which there is a noticeable reduction in the current account deficit that is driven by a disruptive, i.e. recessionary, reduction in foreign capital inflows. ${ }^{14}$ As an alternative, we also use the Frankel and Rose (1996) definition of crisis episodes. For the instrumental variable, we use the Frankel and Rose (2002) dataset to compute gravity estimates for each country in the sample. These are the key variables needed to test the relationship between trade openness and crises.

Using a stacked cross-section, instrumental variables techniques and controls for other plausible determinants of sudden stops, we show that (lack of) trade openness is indeed a powerful predictor of these capital account shocks: moving from Argentina's current trade share (approximately $20 \%$ of GDP) to Australia's average trade share (approximately $30 \%$ of GDP), reduces the probability of a sudden stop by $32 \%$. Some may find this result counterintuitive: trade protectionism does not "shield" countries from the volatility of world markets as proponents might hope. On the contrary, less trade openness leads to greater vulnerability to sudden stops. Finally, using a measure of composite output loss from Frankel and Wei (2004), and instrumental variables techniques, we find evidence

\footnotetext{
${ }^{12}$ Calvo, Izquierdo and Mejia (2003) try to deal with the problem of endogeneity of trade by computing a two-step hierarchical bootstrapped confidence intervals for all variables in the model.

${ }^{13}$ For example, Frankel and Rose (2002) shows that currency unions may raise output, via trade. For a survey of the gravity model in general, and applications and extensions, see chapters 4 and 6 of Frankel (1997).

${ }^{14}$ A reduction in the financial account surplus could potentially be the optimal response to a positive trade shock. To rule out such a case as a crisis episode, we require that a sudden stop be accompanied by a recession. As a matter of fact, this assumption is not essential for the results and we later show that all the findings are robust to alternative definitions of sudden stops.
} 
that openness reduces the output cost associated with the crises that occur, although this result is not as strongly robust as the others.

The paper is organized as follows. In the next section we elaborate on the empirical strategy and discuss the estimation method. Next, we present standard probit results using sudden stop episodes as the dependent variable and confirm the negative correlation between trade openness and the probability of sudden stops that has already been noted in the literature. We then present instrumental variable probit results to show that the direction of causality goes from trade openness to reduced vulnerability to sudden stops. We then repeat the exercise using the Frankel and Rose (1996) definition of crisis episodes and confirm the previous results. Next, we perform several robustness checks, including using a composite output loss variable as the dependent variable in the regressions to test the relationship between openness and the cost of crisis that take place. Finally we discuss results and conclude.

\section{Empirical Strategy}

We begin by testing whether countries that trade more are (all else equal) more or less prone to sudden stops in capital flows. We estimate variants of the following equation:

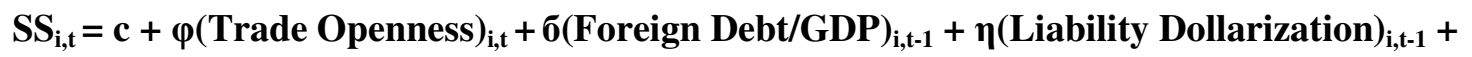
$\chi(\mathrm{CA} / \mathrm{GDP})_{\mathrm{i}, \mathrm{t}-1}+\omega \mathrm{Z}+\mu_{\mathrm{i}, \mathrm{t}}$

where

- "SS $\mathrm{S}_{\mathrm{i}, \mathrm{t}}$ " takes value 1 if a sudden stop hits country " $\mathrm{i}$ " at year " $\mathrm{t}$ " and 0 otherwise,

- "CA/GDP" is the current account balance to GDP, and

- " $Z$ " is a set of lagged and contemporaneous regressors included for robustness check purposes.

Let us begin with the dependent variable. In order to construct $\mathrm{SS}_{\mathrm{i}, \mathrm{t}}$, we follow the Calvo, Izquierdo and Mejia (2003) criteria for a sudden cut in foreign capital inflows (i.e. worsening of the financial account surplus, $F A$ ) that is not the consequence of a positive shock (namely a trade shock). Using a dataset containing annual observations for all the countries in the world with available data in the IMF International Financial Statistics database (IFS) for the period 1970-2002, we compute sudden stop episodes as a reduction in the $\mathrm{CA}$ deficit during the same year as a reduction in $F A$ surplus. To guarantee that this 
reduction in the $\mathrm{CA}$ deficit is not the result of a boom - rising exports imports and income- the episode has to be disruptive, i.e., accompanied by a simultaneous reduction in real output. In words, a sudden stop occurs during the year in which there is a noticeable reduction in the current account deficit that is accompanied by a recessionary reduction in foreign capital inflows. ${ }^{15}$ Based on alternative definitions of what is "noticeable" and "disruptive" we compute four classifications of sudden stops to be used as robustness checks for the results.

The preferred definition is SS1. This algorithm classifies as a sudden stop a situation in which at a year " $t$ ", the financial account surplus of country "i" (prevailing at year "t-1") falls at least two standard deviations below the sample mean; the current account deficit falls by any amount either in " $t$ " or in " $t+1$ "; and GDP per capita falls by any amount either in " $t$ " or in " $t+1$." The overall global pattern of sudden stops under this criterion is summarized in Figure 1.

\section{INSERT FIGURE 1 HERE}

The total number of episodes captured using this methodology is 86 , which is 2.4 percent of total available country/year observations in the dataset. ${ }^{16}$ As Figure 1 shows, these events take place around well-known crises periods: the early 1980's debt crises in Latin America; the 1992-1993 European Monetary System crises; the 1997-1998 Asian crises; and the new wave of crises in developing countries in the late 1990's and early 2000. As shown in the last six columns of the summary statistics table in Appendix A.4, $16 \%$ of all sudden stops occurred in the Asia-Pacific region; $13 \%$ in Europe; $33 \%$ in Latin America; $15 \%$ in the Middle East; $21 \%$ in Africa; and 1\% in South Asia and North America respectively. Alternative definitions show similar patterns of temporal/spatial distribution. ${ }^{17}$

On the regressors side, trade openness is typically measured as a country's ratio of total trade to GDP -- $(\mathrm{X}+\mathrm{M} / \mathrm{Y})$. All these data are readily available from the IFS and the World Development Indicators CD-ROM (WDI) for almost all countries. But, as argued in the Introduction, the problem of using this measure of trade openness is that it might be

\footnotetext{
${ }^{15}$ Technical details are left to the data appendix.

${ }^{16}$ The complete list of crisis episodes per country is in Table A.1. in Appendix A.1.

${ }^{17}$ Graphs are available upon request.
} 
correlated with other unobserved country characteristics, creating identification problems and potentially biased estimators. The contribution we seek to make to the literature is to avoid these problems by using instrumental variables regression techniques. We instrument trade openness by the predicted ratio of trade to GDP based on gravity equations. In its most basic form, the gravity equation captures the intuitive notion that bilateral trade flows are proportional to the product of each country GDP level, and inversely related to the distance between them. Therefore, the "predicted" trade to GDP ratio can be computed from data on countries' geographic characteristics, bilateral trade flows, and GDP. The gravity model has become popular, and there are some very extensive databases that can be used for these computations. We used the dataset at Andrew Rose's webpage, ${ }^{18}$ which is perhaps the most complete one available and has been widely used for empirical research. ${ }^{19}$ Details on the methodology are left to the appendix. The important point is that, to the extent that the "predicted" trade to GDP ratio is highly correlated with the actual trade to GDP ratio ${ }^{20}$, it is a good instrument, because it is less likely that geography is related to economic outcomes through any channel other than trade. In other words, geography is quite plausibly exogenous. A limitation imposed by this methodology is that it does not allow for enough variation in the instrument over time so as to estimate a model with country fixed effects. We don't consider this to be a serious limitation, because most of the variation in trade openness is across countries, not over time.

"Liability Dollarization" introduces the "balance sheet" effects into the empirical model. According to the emerging markets crises literature cited before, the mismatch between the currency denomination of assets and liabilities in the private and public balance sheets of these countries increases the output costs of external shocks that trigger real exchange rate depreciations. Indeed, some sort of "balance sheet" mismatch is required to explain why real depreciations are contractionary in some countries, because in a world

\footnotetext{
${ }^{18}$ http://faculty.haas.berkeley.edu/arose/RecRes.htm

${ }^{19}$ The data set consists of 41,678 bilateral trade observations spanning six different years $(1970,1975,1980$, 1985, 1990, and 1995). All 186 countries, dependencies, territories, overseas departments, colonies, and so forth for which the United Nations Statistical Office collects international trade data are included in the data set. The trade data are taken from the World Trade Database, a consistent recompilation of the U.N. trade data presented in Feenstra, Lipsey, and Bowen (1997), augmented with data from U.N.'s International Trade Statistics Yearbook. This data set is estimated to cover at least $98 \%$ of all trade.

${ }^{20}$ The actual correlation between the variable "trade openness" and the instrument used in this paper is 0.52 .
} 
without these imperfections real depreciations should be expansionary. ${ }^{21}$ We use two alternative measures of "liability dollarization": (i) One is the ratio of foreign liabilities of the financial sector to money (IFS line 26C/Line 34). This is not a direct measure of the extent to which a country's balance sheets present a mismatch in the currency denomination of assets and liabilities. Nevertheless this variable has been used in the literature $^{22}$ as a proxy, primarily because it is available for almost all countries since 1970 and because it should be correlated to actual balance sheet mismatches. (ii) Our alternative proxy is a measure of deposit dollarization from Arteta (2002) and Arteta (2003). This is "Dollar Deposits / Total Deposits" in the financial system. Intuitively, countries with a high percentage of deposit dollarization, but whose domestic currency is not the U.S. dollar, are (most likely) countries whose public and private sectors tend to borrow heavily in a currency different from their own. In Arteta's database, data on the aggregate volume of foreign-currency-denominated (“dollar") deposits of residents are available for 92 developing and transition economies. The time span varies across countries, with some having data from as early as 1975 and some having data only from about 1995 onwards.

"Foreign Debt /GDP" is included to control for the level of financial openness. Without debt to service, there are no sudden stops to worry about. Data for "Foreign Debt/GDP" comes from IFS, where foreign debt is line 89a in that database.

"CA/GDP" is "Current Account Balance/GDP." Its presence controls for the "quantity" of the resource transfer required in the aftermath of a sudden stop in inflows. Data on country's current account balances comes from the WDI CD-ROM.

Finally, " $\mathrm{Z}$ " is a set of (lagged and contemporaneous) regressors included for robustness check purposes. These are:

- "the log of Reserves in months of imports" (because reserves could potentially be used as self-insurance against sudden stops),

- "the log of GDP per capita" (to control for the stage of economic development),

- "FDI / GDP" (the stability of FDI flows could reduce the likelihood of a sudden stop),

- "institutional quality" (to avoid that "trade openness," whether or not instrumented, is incorrectly appropriating effects on sudden stops that really go through institutions),

\footnotetext{
${ }^{21}$ See Cespedes et. al. (2003) for a thorough discussion.

${ }^{22}$ E.g., Alesina and Wagner (2003) and Guidotti et. al. (2003).
} 
- "The ratio of short term debt to total debt" (to control for the effect of the term structure of the debt in the likelihood of a crisis), and

- "ierr", a measure for nominal exchange rate rigidity that is included to test whether monetary policy affects the probability of sudden stops.

All these variables come from WDI CD-ROM, with the exception of the "institutional quality" data, which come from Kaufmann et. al. (2002) and Marshall and Jaggers (2002)'s Polity IV Project, and data on "ierr," which come from Levy Yeyati and Sturzenegger (2003) and are based on their "de-facto" exchange rate classification.

We first present results without instrumental variables, to confirm the existence of a negative correlation between sudden stops and trade openness. Our specification is Probit. Then, we present the results based on instrumental variables for Probit (iv probit). We refrain from reporting panel data (country) fixed-effects results because, as already discussed, most important source of variation is across countries, not within. Summary statistics for all the variables are found in the Appendix A.3, and for all variables tabulated by SS1 in Appendix A.4.

We then run similar regressions where the dependent variable is currency crises, from the Frankel-Rose (1996) and Frankel-Wei (2004) definition, instead of the sudden stop measure. ${ }^{23}$ They define crisis episodes based on the foreign market pressure index. This index is defined as the percentage fall in reserves plus the percentage fall in the foreign exchange value of the currency. The idea is that this index measures the fall in demand for the country's currency; it is then up to the monetary authorities to determine whether to accommodate, by letting the money supply fall, or to depreciate. To avoid treating every year of a multi-year high-inflation period as a separate crisis, the approach followed by the authors requires that the increase in exchange market pressure represent an acceleration of at least an additional 10 percent over the preceding period to be considered a crisis episode; and they also adopt an exclusion window of 3 years. The total number of episodes captured using this methodology is 419 which is 13 percent of total available country/year observations in the dataset. This means that the alternative way of computing crisis episodes is much more comprehensive than the sudden stop criterion. The overall global pattern of crises events under this criterion is summarized in Figure 2. As can be

\footnotetext{
${ }^{23}$ Summary statistics are in Appendix A.3
} 
readily observed in Figure 2, the peak in the number of episodes captured using this methodology is also centered around well-known crisis periods. ${ }^{24}$

\section{INSERT FIGURE 2 HERE}

\section{Results}

We begin by estimating non-instrumental variables variants of equation (1), using a stacked cross-section. We compute standard errors robust to clustered heteroskedasticity. All independent variables -- other than trade openness and effectiveness of government-are lagged one period. ${ }^{25}$ Results include year fixed effects and regional dummies, but these coefficients are not reported here. ${ }^{26}$ The results reported here are based on "SS1," but all estimates are robust to the use of alternative definitions of sudden stops. ${ }^{27}$ We do not exclude contiguous crisis episodes, but all the results reported here are robust to the inclusion of a one-year, two-sided omission window around crisis episodes.

The explanatory power of the regressions is not high. This is not surprising; it is consistent with the performance of standard models of crises and the usual inability of leading-indicator exercises to properly predict events. ${ }^{28}$ Table 1 summarizes the results for some variants of (1) using non-instrumental variables Probit specification.

As a measure of institutional quality we report the coefficient on "effectiveness of government" which is one of the six proxies of institutional quality in Kaufman et. al. (2002). ${ }^{29}$ The institutional quality data in Kaufman et. al. (2002) are not in panel form, so every country in the sample is assigned a single (time-invariant) value. As additional robustness checks, we also use Marshall and Jaggers (2002)'s Polity IV Project data, which

\footnotetext{
${ }^{24}$ For further details on the methodology and additional summary statistics, please refer to Frankel and Wei (2004)

${ }^{25}$ Introducing contemporaneous rather than lagged variables does not affect the results.

${ }^{26}$ Further details on the results and robustness checks are available upon request.

${ }^{27} \mathrm{We}$ use three alternative definitions. The details are in the data appendix.

${ }^{28}$ See, for example, Arteta (2003)

${ }^{29}$ All the results reported here are qualitatively and quantitatively robust to the inclusion of any of the other five proxies proposed in that paper. These are: "Voice and Accountability", "Control of Corruption", "Rule of Law", "Political Stability/Lack of Violence", and "Regulatory Framework".
} 
is panel (country/year). ${ }^{30}$ Using this alternative measure does not change the results, so we don't report them.

\section{INSERT TABLE 1 HERE}

Table 1 confirms the existence of a negative correlation between trade openness and the likelihood of a sudden stop, as previously documented in Calvo, Izquierdo and Mejia (2003) and Edwards (2004). Nevertheless, the methodology employed in these papers can not guarantee the exogeneity of trade openness and therefore, falls short of establishing causality.

As for the other regressors, interestingly, the coefficient on "Foreign Debt / GDP" does not appear statistically significant across most of the variants in Tables 1 or $2 .^{31}$ The last column in Table 1 shows that the result for trade openness is robust to the exclusion of the debtvariable from the regression. This is consistent with the hypothesis that different countries are able to tolerate different levels of debts. ${ }^{32}$

Similarly, the coefficient that seeks to capture the "balance sheet" effects -Liability Dollarization -- is positive but not always statistically significant when definition (i) is used and always insignificant when Arteta's dollarization definition (ii) is used instead. ${ }^{33}$ This result suggests that these measures of dollarization appear not to have significant detrimental effects in terms of increased vulnerability to sudden stops. Column 4

\footnotetext{
30 It provides a measure of the political regime's characteristics [either democracy (high values) or autocracy (low values)] rather that institutional quality per se. In particular: POLITY2 (numeric). Range $=-10$ to 10 ($10=$ high autocracy; $10=$ high democracy). Combined Polity Score: Computed by subtracting AUTOC from DEMOC; normal range polity scores are imputed for coded "interregnum" and "transition period" special polity conditions, polities coded "interruption" on the POLITY variable are left blank.

31 Similarly, Calvo, Izquierdo and Mejia. (2003) don't find a significant effect of total public debt in their probit regressions for sudden stops, nor do Frankel and Rose (1996) in their probit regressions of currency crashes.

${ }^{32}$ We also tried "Foreign Debt/Exports" in lieu of "Foreign Debt/GDP." In theory, the insignificance of 6 could be due to the fact that both "Foreign Debt" and "GDP" are measured in domestic currency, but the former potentially has a larger component of foreign currency, so "Foreign Debt/GDP" could be underestimating financial openness before a sudden stop (if the real exchange rate was overvalued) and simultaneously overestimating financial openness after sudden stop (if the real exchange rate overshoots expost). Nevertheless, the results using "Foreign Debt/Exports" do not change from those reported using "Foreign Debt/GDP." [Unfortunately, series for exports in domestic currency are not as widely available as series for GDP, so we have fewer observations for this variable.]

${ }^{33}$ Note that when Arteta's definition is used, many data points are lost. Nevertheless, the coefficient on trade openness appears to increase a lot when the sample is restricted using Arteta's dollarization data.
} 
in Tables 1 shows that results are robust to the exclusion of any of the proxies for dollarization from the regressions (as long as some of the other controls remain in place). ${ }^{34}$

Finally, the coefficient that controls for the size of the transfer in the aftermath of the sudden stop -- CA / GDP -- is negative and statistically significant across all variants. The implication is as conjectured: a sudden stop is more likely when a larger resource transfer is expected in its aftermath (i.e., when the initial CA deficit is high).

As for the other controls: the coefficient on short term debt to total debt appears as small and positive, but (weakly) statistically significant only in one of the variants of (1). This suggests that the term structure of the debt appears not to have a significant effect on the probability of a sudden stop. The coefficient on the index of rigidity of the nominal exchange rate is positive but statistically insignificant in the regressions. The rest of the controls, including institutional quality proxies, never appear as statistically significant and all the results are robust to the inclusion or exclusion of these variables from the regressions. Regional dummies (not reported) are always insignificant.

Now we come to what we hope is our contribution to the state of the art. Table 2 presents instrumental variable estimates for probit. ${ }^{35}$

\section{INSERT TABLE 2 HERE}

The results are qualitatively very similar to those in Table 1, although the point estimates of the coefficient on trade openness are quantitatively different. Interestingly, when we use gravity estimates as instrumental variables for trade openness, the point estimates are noticeably bigger in absolute value. This means that correcting for the

\footnotetext{
${ }^{34}$ In our preferred model, liability dollarization is part of the story whereby trade openness can be expected to have an effect on the probability of a sudden stop. The fact that the coefficient on trade openness remains statistically significant even after excluding liability dollarization from the regressions, however, may mean that it works through one of the other channels discussed in the introduction. Or it may be due to the fact that some of the other controls (in particular, foreign debt/GDP) also capture liability dollarization if most foreign debt is denominated in foreign currencies as it is usually the case in crisis prone countries. Without any additional control, trade openness does not appear as statistically significant in the non-IV regressions, in spite of the fact that the controls themselves are rarely significant.

35 The STATA module used to run these regressions is due to Gelbach (1999) and it implements the method of Whitney Newey, "Efficient Estimation of Limited Dependent Variable Models with Endogenous Explanatory Variables”, Journal of Econometrics (1987).
} 
potential sources of endogeneity, the effect of trade openness on the probability of sudden stop is even stronger than what one would be led to conclude from the OLS regressions.

From the point estimates of the coefficient on trade openness we can estimate the average change in the probability of an event occurring as the result of a unit change in the value of trade openness. ${ }^{36}$ This number is approximately $-0.077,{ }^{37}$ meaning that an increase in trade openness of 10 percentage points decreases the likelihood of a sudden stop by approximately $32 \% .^{38}$ That is, a country that only trades $20 \%$ of GDP (i.e. Argentina) is, ceteris paribus, $32 \%$ more likely to be hit by a sudden stop than a country that trades $30 \%$ of GDP (i.e. Australia).

The rest of the point estimates are qualitatively similar to those found in Table 1. Two differences are notable. (i) The estimated coefficient on trade openness remains strongly negative and statistically significant even when the variable "Foreign Debt / GDP" is excluded from the regressions. (ii) The coefficient on "Liability Dollarization" appears positive and statistically significant when the variable "Short Term Debt / Total Debt" is excluded from the regressions. In spite of these results, it is worth reemphasizing that the methodology here only promises the exogeneity of trade openness, so no causal relationship can be derived from the other estimates.

Next, we redo the exercise using the Frankel-Rose and Frankel-Wei definition of crises as the dependent variable. In Table 3 we report standard probit results, and in Table 4 we present IV probit results with gravity estimates as the instrumental variable for trade. The results are consistent with those reported before.

\section{INSERT TABLE 3 HERE}

\footnotetext{
${ }^{36}$ Note that in a linear regression model the slope coefficient of a regressor measures the effect on the average value of the regressand for a unit change in the value of the regressor. In probit the rate of change in the probability is somewhat complicated and given by $\beta_{\mathrm{j}}{ }^{*} \varnothing\left(\mathrm{Z}_{\mathrm{i}}\right)$, where $\beta_{\mathrm{j}}$ is the coefficient of the jth regressor and $\varnothing($.$) is the density function of the standard normal variable where Z_{i}=\beta X$, that is, the regression model used in the analysis.

${ }^{37}$ This average is based on reported and not reported regressions.

${ }^{38}$ A 10 percentage point increase in the independent variable "trade openness" is, for example, an increase from the mean value of this variable in the sample, which is 0.63 , to 0.73 (see appendix A.3. for summary statistics); or, equivalently, an increase in trade openness of approximately two standard deviations above the sample mean. Given the estimated coefficient on trade openness, this 0.10 increase in the independent variable decreases the left hand side by: $0.10 *(-0.077)=-0.0077$. The left hand-side variable is either " 0 ' $s$ " or " 1 's". Because $2.39 \%$ of the observations in the sample are 1 's, a -0.0077 change in the left hand side variable
} 


\section{INSERT TABLE 4 HERE}

The main highlights are:

- Openness reduces the probability of a currency crisis. The point estimates are not as large in absolute value as those obtained when using "SS1;" but the new coefficients are always statistically significant at standard confidence levels and the instrumental variables results are still stronger than the standard probit results. This reinforces the point already made, that correcting for the potential sources of endogeneity, the effect of trade openness on the probability of an external crisis is even stronger than what one would be led to conclude from the OLS regressions that use the trade to GDP ratio as a measure of openness.

- The coefficient on "Foreign Debt / GDP" is positive and statistically significant in most of the IV probit regressions, suggesting that the presence of a large stock of foreign debt as a percentage of GDP increases the probability of crisis. The result is not robust in the standard probit regressions and is idiosyncratic to this particular definition of crisis episodes.

- The coefficient on the log of Reserves, in months of imports, is systematically negative and statistically significant across both, standard and IV probit regressions. This suggests that having a large stockpile of reserves reduces the probability of being hit by a crisis. This result is interesting because this variable is always insignificant in the regressions that use "SS1" as the dependent variable. The most likely reason for the difference is the way in which crises are defined in both cases. Frankel-Rose definition of crisis episodes uses the foreign exchange market pressure index which itself includes change in Reserves in the definition, while "SS1" does not.

- The coefficient on "ierr" is positive and statistically significant across most of the regressions in both tables. This suggests that having a peg increases the chances of being hit by a crisis. This result is also idiosyncratic to this definition of crisis episodes.

means that there is a decrease in the probability of observing a 1 instead of a 0 (i.e. observing a sudden stop) of approximately $(-0.0077 / 0.0239) * 100=-32 \%$ 
- The coefficient on "CA / GDP" is systematically insignificant across all regressions. This is also different from the case in which the dependent variable is "SS1". Once again the most likely reason is the definition of the crisis variable itself. Recall that "SS1" is built upon the assumption that there is an outstanding current account deficit that has to be abruptly reduced in the presence of a crisis; while in the alternative definition of crises, an episode can occur independently of what happens to the current account if the government is willing to give up reserves to finance an outstanding deficit.

- All of the aforementioned results are even stronger in statistical significance when regional dummies are excluded from the regressions.

The rest of the controls never appear as statistically significant, but all the results are robust to the inclusion or exclusion of these variables from the regressions. Regional dummies (not reported) are always insignificant. We find it reassuring that we get very similar results using two very different definitions of crises. We also get some additional results in terms of other variables that increase or reduce the probability of a crisis, but we choose not to emphasize these so strongly because the methodology we propose here only promises the exogeneity of openness.

\section{Robustness Checks}

Finally, we perform a variety of robustness checks. We redo all regressions using linear models rather than probit. All of the aforementioned results are robust to this alteration. We report these regressions in Tables 5 and 6 in Appendix A.5. In table 7 in the same appendix we report results for instrumental variables GLS random effects estimates. Reassuringly, results are both quantitatively and qualitative similar to those in the comparable Table $6 .^{39}$

The next step is to look at an alternative dependent variable, one that combines crisis episodes with the depth of the crisis, where the latter is measured in terms of the recessionary impact of an event. We choose to use the sum of output lost during crises (and

\footnotetext{
${ }^{39}$ Unfortunately, the STATA module used to compute instrumental variables probit (Table 1) does not allow running random effects instrumental variables probit regressions. So there is no table analogous to Table 5 but for probit regressions. Nevertheless, and somewhat reassuringly, random effects non-instrumental variables probit models yield almost identical results to those of plain probit (i.e. Table 4).
} 
up to three years after the crisis), excluding from that summation cases where crises were associated with output gain. We borrow this variable from Frankel and Wei (2004). ${ }^{40}$ Given the nature of the dependant variable, which is censored to the left of the distribution at zero, the natural candidate for the estimation is a Tobit model. We perform Tobit and iv Tobit regressions and report the typical results in the first two columns in Table 8 in Appendix A.5. ${ }^{41}$ We find that openness tends to dampen the contractionary effects of crises, but the effect is not robust in the IV regressions. We also find that the "Foreign Debt / GDP", the "Short Term Debt / Total Debt" and "Liability Dollarization" typically enter regressions with a positive coefficient, meaning that the presence of all these increases the recessionary effect of crises. Finally, the "Lag of reserves in months of imports" is typically negative and statistically significant, meaning that the presence of a large stockpile of reserves tends to dampen the recession that might come in the aftermath of an external crisis. In columns 3 and 4 of Table 8 , we also report IV linear and IV probit results which depict a similar picture. The only noticeable difference is that in the IV probit regressions the coefficient on openness is typically statistically significant. All the other controls are never statistically significant.

The evidence suggests that openness tends to reduce the contractions that might follow crisis episodes, but the results are not as robust as those we obtain using sudden stops or currency crises as the dependent variable. In particular, they are not always strong in IV tobit regressions.

\section{$\underline{\text { V. Conclusion }}$}

In summary, the evidence overall appears to be quite robust. Economies that trade less with other countries are more prone to sudden stops and to currency crashes. Controlling for other plausible determinants of these shocks and instrumenting trade openness by gravity estimates to avoid identification problems, we find a causal link between lack of openness to trade and the instability of financial flows. In fact out of the set of controls we tried, only trade openness and the size of current account deficit before

\footnotetext{
${ }^{40}$ Summary statistics are in Appendix A.3.

${ }^{41}$ The STATA module used to run these regressions is due to Gelbach (1999b) and it implements the method of Whitney Newey, "Efficient Estimation of Limited Dependent Variable Models with Endogenous Explanatory Variables", Journal of Econometrics (1987).
} 
the shock appear as significant predictors of sudden stops. Trade openness, foreign debt, reserves and the nominal exchange rate rigidity also appear as significant predictors of the other form of external crises analyzed.

The effect of trade openness on the probability of sudden stop appears to be not only qualitatively robust, but also quantitatively significant. A conservative estimate (based on the average point estimate of the reported and unreported coefficients on trade openness) yields the surprising result that, all else equal, increasing the trade to GDP ratio by 10 percentage points (i.e. going from Argentina's current trade share to Australia's average trade share) reduces the probability of a sudden stop by approximately $32 \%$. We also find some evidence that more openness reduces the output cost associated with crises, although these results are not as robust as those that point to the connection between openness and the probability of crises. 


\section{References}

Aizenman, Joshua, (2003), "On the Hidden Links Between Financial and Trade Opening", NBER Working Paper No. 9906.

Aizenman, Joshua, and I. Noy (2004), "On the Two Way Feedback between Financial and Trade Openness", NBER Working Paper No. 10496.

Alesina, Alberto and Alexander Wagner, (2003), "Choosing (and reneging on) Exchange Rate Regimes”, NBER Working Paper No. 9809.

Arteta, Carlos, (2002), "Exchange Rate Regimes and Financial Dollarization: Does Flexibility Reduce Bank Currency Mismatches?" International Finance Discussion Paper 738, Board of Governors of the Federal Reserve System (September).

Arteta, Carlos, (2003), "Are financially dollarized countries more prone to costly crises?" International Finance Discussion Paper 763, Board of Governors of the Federal Reserve System (March).

Aghion, P., P. Bacchetta, and A. Banerjee (2000), "A Simple Model of Monetary Policy and Currency Crises”, European Economic Review, 44 (4-6): 728-738.

Caballero, R., and A. Krishnamurthy (2003), "Excessive Dollar Debt: Financial Development and Underinsurance", Journal of Finance, Vol. LVIII, No. 2: 867-893

Calvo, Guillermo, Alejandro Izquierdo, and Ernesto Talvi, (2003), "Sudden Stops, The Real Exchange Rate, and Fiscal Sustainability: Argentina's Lessons." NBER Working Paper 9828. National Bureau of Economic Research, Cambridge, Mass.

Calvo Guillermo A., Alejandro Izquierdo and Luis Fernando Mejia, (2003), "On the Empirics of Sudden Stops”. Inter-American Development Bank Working Paper.

Calvo, Guillermo, and Ernesto Talvi, 2004, "Sudden Stop, Financial Factors and Economic Collapse: A View from the Latin American Frontlines," in From the Washington Consensus Towards a New Global Governance, Barcelona, Sept. 24-26.

Calvo, Guillermo A., (1998), "Capital Flows and Capital-Market Crises: The Simple Economics of Sudden Stops", Journal of Applied Economics (CEMA), 1(1):35-54.

Cavallo, Eduardo A., (2004), "Trade, Gravity and Sudden Stops: On How Commercial Trade can increase the stability of capital flows", mimeograph, Harvard University.

Cavallo, Michelle, Kate Kisselev, Fabrizio Perri and Nouriel Roubini, (2002), "Exchange Rate Overshooting and the Costs of Floating", mimeograph, New York University. 
Céspedes, L.F., R. Chang and A. Velasco, (2000), "Balance Sheets and Exchange Rate Policy", NBER Working Paper no. 7840.

Céspedes, L.F., R. Chang and A. Velasco, (2003), "IS-LM-BP in the Pampas", IMF Staff Papers, Vol. 50, (special issue): 143-156.

Chang, Roberto and A. Velasco, (1999), "Financial Crises in Emerging Markets, A Canonical Model”, FRBA, Vol. 84, no. 2 (Second Quarter): 4-17.

Christiano, L.J., C. Gust and J. Roldos, (2002), "Monetary Policy in a Financial Crisis", Journal of Economic Theory, forthcoming.

Desai, Padma, and Pritha Mitra (2004), "Why Do Some Countries Recover More Readily from Financial Crises," Columbia University, July.

Dooley, Michael, (2000), "Can Output Losses Following International Financial Crises be Avoided?", NBER Working Paper 7531. National Bureau of Economic Research, Cambridge, Mass.

Dornbusch Rudiger (2001), "A Primer on Emerging Market Crises," NBER Working Paper No. 8326. Published in Managing Currency Crises in Emerging Markets, S. Edwards and J. Frankel, eds., Chicago: University of Chicago Press, 2002.

Dornbusch, Rudiger, Ilan Goldfajn and Rodrigo Valdes, (1995), "Currency Crises and Collapses", Brooking Papers on Economic Activity, 2: 219-293.

Easterly, W., R.Islam and J. Stiglitz (2001), "Shaken and Stirred: Explaining Growth Volatility," Annual World Bank Conference on Development Economics, edited by B. Plesokovic and N. Stern.

Eaton, Jonathan and Mark Gersovitz (1981), "Debt with Potential Repudiation: Theoretical and Empirical Analysis", The Review of Economic Studies, Vol. 48, No.2 (Apr., 1981), 289-309.

Edwards, Sebastian, (2004a), "Financial Openness, Sudden Stops and Current Account Reversals", NBER Working Paper No. 10277. American Economic Review 94, no.2, May 59-64.

Edwards, Sebastian, (2004b), "Thirty Years of Current Account Imbalances, Current Account Reversals and Sudden Stops," NBER WP no. 10276, January. In IMF Staff Papers.

Feenstra, Robert, Robert Lipsey, and Harry Bowen (1997), "World Trade Flows, 19701992, with Production and Tariff Data”. NBER Working Paper No. 5910.

Frankel, Jeffrey (1997), "Regional Trading Blocs”, Institute for International Economics. Washington, DC. 
Frankel, Jeffrey, and David Romer, (1999), "Does Trade Cause Growth?", American Economic Review, Vol. 89, No. 3: 379-399.

Frankel, Jeffrey, and Andrew K. Rose (1996), "Currency Crashes in Emerging Markets: An Empirical Treatment," Journal of International Economics 41: 351-368.

Frankel, Jeffrey, and Andrew K. Rose, (2002), "An Estimate of the Effect of Common Currencies on Trade and Income", Quarterly Journal of Economics, Vol 117, Issue 2 (May): 437-466

Frankel, Jeffrey, and Shang-Jin Wei (2004), "Managing Macroeconomic Crises: Policy Lessons," Chapter 7, in Economic Volatility and Crises: A Policy-Oriented Guide, edited by Joshua Aizenman and Brian Pinto, World Bank, Washington DC, 2004.

Gelbach, Joseph (1999), "PROBITIV: Stata module to perform instrumental variables probit", in Statistical Software Components from Boston College Department of Economics. Available online: http://econpapers.hhs.se/software/bocbocode/s371401.htm.

Gelbach, Joseph (1999b), "TOBITIV: Stata module to perform instrumental variables tobit", in Statistical Software Components from Boston College Department of Economics. Available online: http://econpapers.hhs.se/scripts/search.asp?ft=tobitiv.

Guidotti, Pablo, Federico Sturzenegger and Agustin Villar, (2003), "On the Consequences of Sudden Stops", Economia, forthcoming.

Kaufmann, D., A. Kraay, and P. Zoido-Lobatón. (2002), "Governance Matters II—Updated Indicators for 2000/01," World Bank Policy Research Department Working Paper No. 2772, Washington D.C.

Kiyotaki, N. and J. Moore, (1997), "Credit Cycles", Journal of Political Economy 105 (2), 211-248.

Kose, M. Ayhan, Eswar Prasad, and Marco Perrones (2004), "How do Trade and Financial Integration Affect the Relationship Between Growth and Volatility?" International Monetary Fund, August.

Krugman Paul, (1999), "Balance Sheets Effects, the Transfer Problem and Financial Crises," in International Finance and Financial Crises: Essays in Honour of Robert P. Flood, Jr., Isard P., A. Razin and A.K. Rose (eds.), Kluwer Academic Publishers, pp. 3144.

Levy Yeyati, Eduardo, and Federico Sturzenegger (2003), "A de facto Classification of Exchange Rate Regimes: A Methodological Note", posted at http://www.aeaweb.org/aer/contents/ of American Economic Review, Vol. 93 (September), No. 4. 
Marshall, Monty G., and Keith Jaggers (2002), "Polity IV Project, Political Regime Characteristics and Transitions, 1800-2002". Integrated Network for Societal Conflict Research (INSCR) Program. Center for International Development and Conflict Management (CIDCM), University of Maryland, College Park 20742. www.cidcm.umd.edu/inscr/polity

Mendoza, Enrique, (2002), "Credit, Prices and Crashes: Business Cycles with a Sudden Stop", in Preventing Currency Crises in Emerging Markets, Frankel, J. and S. Edwards (eds.), Chicago, IL: University of Chicago Press.

Milesi-Ferretti, Gian Maria, and Assaf Razin (1998) "Sharp Reductions in Current Account Deficits: An Empirical Analysis." NBER Working Paper 6310. European Economic Review 42 (3--5), May: 897--908.

--------. 2000. "Current Account Reversals and Currency Crises: Empirical Regularities." NBER Working Paper 6620. . In Paul Krugman, ed., Currency Crises. Chicago: University of Chicago Press.

Prasad, Eswar, Kenneth Rogoff, Shang-Jin Wei, and M. Ayhan Kose (2003), "Effects of Financial Globalization on Developing Countries: Some Empirical Evidence," Occasional Paper No. 220, Research Department, International Monetary Fund.

Rose, Andrew, (2002), "A Reason Why Countries Pay their Debts: Renegotiation and International Trade”, NBER Working Paper \#8853

Sachs, Jeffrey D, (1985), "External Debt and Macroeconomic Performance in Latin America and East Asia," Brookings Papers on Economic Activity, 1985:2. 
Figure 1: Sudden Stop 1

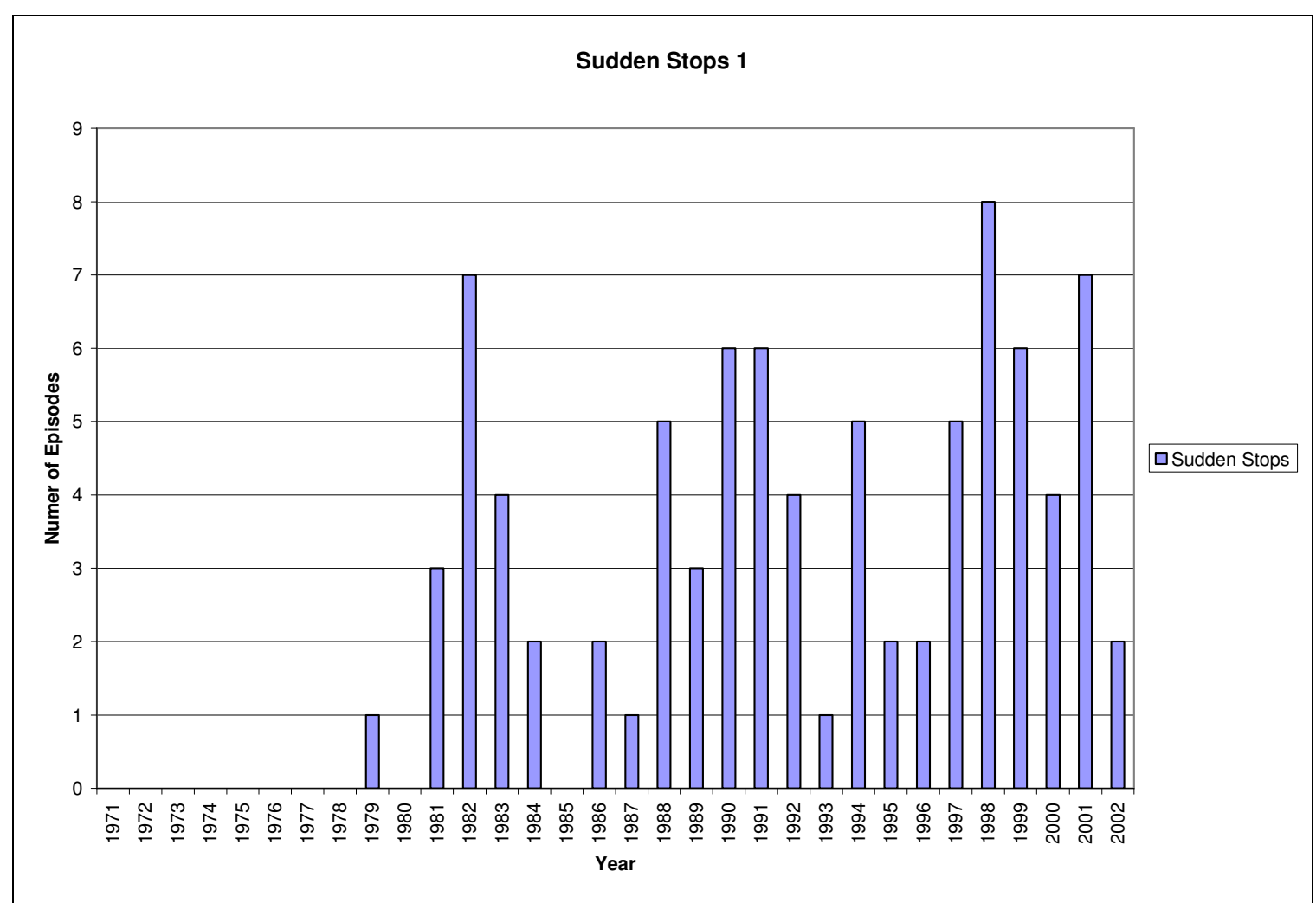

Source: Author's computations 
Figure 2: Crises Episodes based on "foreign exchange market pressure index" [Frankel and Wei (2004)]

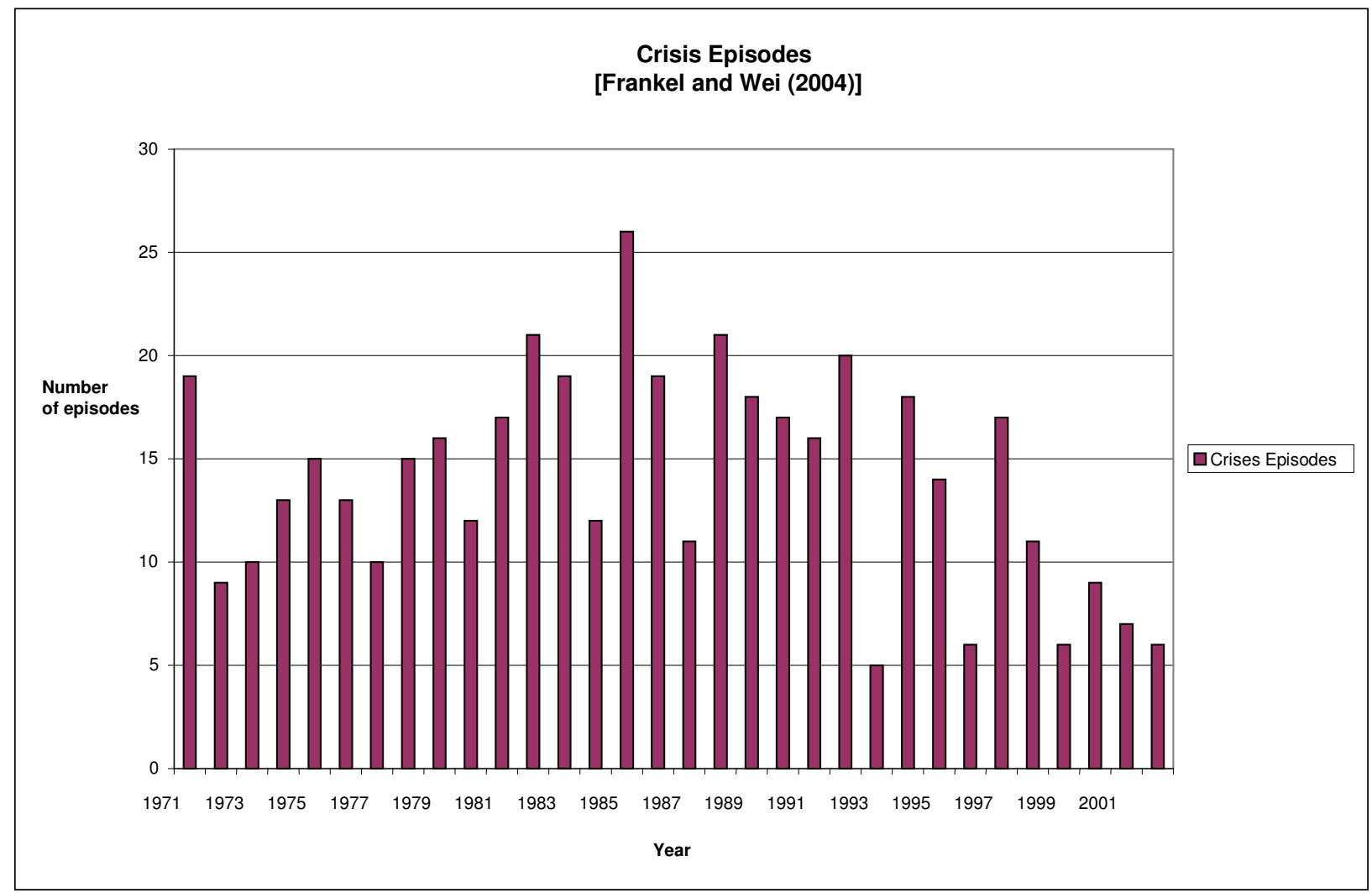

Source: Author's computations 
Table 1: Non - Instrumental variables Probit Regressions

\begin{tabular}{|c|c|c|c|c|c|c|c|c|c|}
\hline & \multicolumn{9}{|c|}{ Dependent Variable: Sudden Stop 1} \\
\hline Trade openness $t$ & $\begin{array}{c}\mathbf{- 0 . 5 3} \\
(0.259)^{* *}\end{array}$ & $\begin{array}{c}\mathbf{- 0 . 8 6} \\
(0.343)^{* *}\end{array}$ & $\begin{array}{c}\mathbf{- 3 . 0 1} \\
(0.998)^{* *}\end{array}$ & $\begin{array}{l}\mathbf{- 1 . 0 2 5} \\
(0.671)\end{array}$ & $\begin{array}{c}\mathbf{- 0 . 8 9 8} \\
(0.348)^{* *}\end{array}$ & $\begin{array}{c}\mathbf{- 0 . 6 9 1} \\
(0.329)^{* *}\end{array}$ & $\begin{array}{c}\mathbf{- 0 . 7 0 5} \\
(0.278) * *\end{array}$ & $\begin{array}{c}\mathbf{- 0 . 8 3 1} \\
(0.344)^{* *}\end{array}$ & $\begin{array}{c}\mathbf{- 0 . 4 7 9} \\
(0.247)^{*}\end{array}$ \\
\hline $\begin{array}{l}\text { Foreign Debt/ } \\
\text { GDP }_{\text {t-1 }}\end{array}$ & $\begin{array}{l}\mathbf{- 0 . 0 8 0} \\
(0.217) \\
\end{array}$ & $\begin{array}{c}\mathbf{- 0 . 0 7} \\
(0.243) \\
\end{array}$ & $\begin{array}{l}\mathbf{- 0 . 8 6 0} \\
(0.685) \\
\end{array}$ & $\begin{array}{c}\mathbf{- 0 . 9 9 5} \\
(0.453)^{* *} \\
\end{array}$ & $\begin{array}{c}\mathbf{- 0 . 0 2 8} \\
(0.238) \\
\end{array}$ & $\begin{array}{l}\mathbf{- 0 . 1 4 4} \\
(0.243) \\
\end{array}$ & $\begin{array}{l}\mathbf{- 0 . 0 6 3} \\
(0.236) \\
\end{array}$ & $\begin{array}{l}\mathbf{- 0 . 0 8 7} \\
(0.235) \\
\end{array}$ & \\
\hline $\begin{array}{l}\text { Short Term Debt/ } \\
\text { Total Debt t-1 }\end{array}$ & & $\begin{array}{c}\mathbf{0 . 9 5 1} \\
(0.855)\end{array}$ & $\begin{array}{c}\mathbf{5 . 2 5 3} \\
(2.567)^{* *}\end{array}$ & $\begin{array}{c}\mathbf{1 . 8 2 9} \\
(1.553)\end{array}$ & $\begin{array}{l}\mathbf{1 . 1 6 8} \\
(0.765)\end{array}$ & & $\begin{array}{c}\mathbf{0 . 5 5 3} \\
(0.686)\end{array}$ & $\begin{array}{l}\mathbf{0 . 9 7 7 6} \\
(0.772)\end{array}$ & $\begin{array}{c}\mathbf{0 . 3 5 8} \\
(0.601)\end{array}$ \\
\hline $\begin{array}{l}\text { Liability } \\
\text { Dollarization t-1 } \\
\text { (1) }\end{array}$ & $\begin{array}{c}\mathbf{0 . 3 1 6} \\
(0.195)\end{array}$ & $\begin{array}{c}\mathbf{0 . 2 3 6} \\
(0.266)\end{array}$ & & $\begin{array}{c}\mathbf{0 . 5 9 9} \\
(0.229)^{* *}\end{array}$ & & $\begin{array}{c}\mathbf{0 . 3 9 9} \\
(0.216)^{* *}\end{array}$ & $\begin{array}{c}\mathbf{0 . 2 4 4} \\
(0.242)\end{array}$ & $\begin{array}{c}\mathbf{0 . 3 2 4} \\
(0.268)\end{array}$ & $\begin{array}{c}\mathbf{0 . 3 0 2} \\
0.2455\end{array}$ \\
\hline $\begin{array}{l}\text { Liability } \\
\text { Dollarization t-1 } \\
\text { (2) }\end{array}$ & & & $\begin{array}{c}\mathbf{0 . 7 3 3} \\
(1.416)\end{array}$ & & & & & & \\
\hline $\begin{array}{l}\text { Exchange Rate } \\
\text { Rigidity Index t-1 }\end{array}$ & & & & $\begin{array}{c}\mathbf{0 . 2 2 4} \\
(0.146)\end{array}$ & & & & & \\
\hline $\begin{array}{l}\text { Current Account/ } \\
\text { GDP }_{\text {t-1 }}\end{array}$ & $\begin{array}{c}\mathbf{- 4 . 0 6 8} \\
(1.297)^{* *} \\
\end{array}$ & $\begin{array}{c}\mathbf{- 5 . 4 1 7} \\
(1.902)^{* *} \\
\end{array}$ & $\begin{array}{c}\mathbf{- 9 . 6 9} \\
(2.86)^{* * *} \\
\end{array}$ & $\begin{array}{c}\mathbf{- 8 . 6 8} \\
(2.928)^{* *} \\
\end{array}$ & $\begin{array}{c}\mathbf{- 5 . 6 0} \\
(1.888)^{* *} \\
\end{array}$ & $\begin{array}{c}\mathbf{- 4 . 9 8} \\
(1.781)^{* *} \\
\end{array}$ & $\begin{array}{c}\mathbf{- 4 . 9 9} \\
(1.632)^{* *}\end{array}$ & $\begin{array}{c}\mathbf{- 5 . 5 0} \\
(1.862)^{* *} \\
\end{array}$ & $\begin{array}{c}\mathbf{- 3 . 4 2} \\
(1.308)^{* *}\end{array}$ \\
\hline FDI/GDP $_{t-1}$ & & & & $\begin{array}{l}\mathbf{- 0 . 0 9 7 4} \\
(0.074) \\
\end{array}$ & & & & & \\
\hline $\begin{array}{l}\text { Ln Reserves in } \\
\text { Months of } \\
\text { Imports } t-1\end{array}$ & & & & $\begin{array}{c}\mathbf{- 0 . 1 2 1} \\
(0.1165)\end{array}$ & & & & & \\
\hline $\begin{array}{l}\text { Ln GDP } \\
\text { per capita } t-1\end{array}$ & & $\begin{array}{c}\mathbf{0 . 0 3 5} \\
(0.190) \\
\end{array}$ & & $\begin{array}{c}\mathbf{- 0 . 0 7 5} \\
(0.223) \\
\end{array}$ & $\begin{array}{c}\mathbf{0 . 0 3 7} \\
(0.193)\end{array}$ & $\begin{array}{c}-\mathbf{0 . 1 0 1} \\
(0.136)\end{array}$ & $\begin{array}{c}\mathbf{0 . 1 0 6} \\
(0.134)\end{array}$ & & $\begin{array}{c}\mathbf{0 . 1 7 5} \\
(0.152)\end{array}$ \\
\hline $\begin{array}{l}\text { Effectiveness of } \\
\text { Government } t\end{array}$ & & $\begin{array}{c}\mathbf{0 . 1 4 1} \\
(0.268) \\
\end{array}$ & & $\begin{array}{l}\mathbf{0 . 4 1 4 3} \\
(0.359) \\
\end{array}$ & $\begin{array}{l}\mathbf{0 . 1 7 0} \\
(0.269) \\
\end{array}$ & $\begin{array}{l}\mathbf{- 0 . 0 5 9} \\
(0.245) \\
\end{array}$ & & $\begin{array}{c}\mathbf{0 . 1 3 7} \\
(0.201) \\
\end{array}$ & $\begin{array}{l}\mathbf{0 . 0 6 5} \\
(0.187) \\
\end{array}$ \\
\hline $\begin{array}{c}\text { Regional } \\
\text { Dummies? }\end{array}$ & YES & YES & YES & YES & YES & YES & YES & YES & \\
\hline $\begin{array}{l}\text { Year Fixed- } \\
\text { Effects? }\end{array}$ & YES & YES & YES & YES & YES & YES & YES & YES & \\
\hline Constant & $\begin{array}{c}\mathbf{- 2 . 5 4 4} \\
(0.63)^{* * *}\end{array}$ & $\begin{array}{l}\mathbf{- 2 . 0 6 5} \\
(1.383)\end{array}$ & $\begin{array}{c}\mathbf{- 0 . 2 4 4} \\
(1.099)\end{array}$ & $\begin{array}{l}\mathbf{- 1 . 9 9} \\
(1.73)\end{array}$ & $\begin{array}{l}\mathbf{- 2 . 1 6 5} \\
(1.372)\end{array}$ & $\begin{array}{l}\mathbf{- 1 . 2 5 5} \\
(1.064)\end{array}$ & $\begin{array}{c}\mathbf{- 2 . 6 2} \\
(1.121)^{* *}\end{array}$ & $\begin{array}{c}\mathbf{- 1 . 9 5} \\
(0.737)^{* *}\end{array}$ & $\begin{array}{c}\mathbf{- 3 . 2 1} \\
(1.08)^{* *}\end{array}$ \\
\hline Obs. & 778 & 464 & 113 & 296 & 447 & 597 & 564 & 508 & 904 \\
\hline $\mathbf{R}^{2}$ & 0.0992 & 0.1154 & 0.2927 & 0.2033 & 0.1115 & 0.1178 & 0.1037 & 0.1156 & 0.0872 \\
\hline
\end{tabular}

Robust standard errors reported in parenthesis.

$* * *$ Statistically Significant at $1 \%$

** Statistically Significant at 5\%

* Statistically Significant at $10 \%$ 
Table 2: Instrumental Variables Probit Regressions

\begin{tabular}{|c|c|c|c|c|c|c|c|c|c|}
\hline & \multicolumn{9}{|c|}{ Dependent Variable: Sudden Stop 1} \\
\hline Trade openness $t$ & $\begin{array}{c}\mathbf{- 2 . 4 5} \\
(0.813)^{* *} \\
\end{array}$ & $\begin{array}{c}\mathbf{- 3 . 4 7} \\
(1.419)^{* *} \\
\end{array}$ & $\begin{array}{c}\mathbf{- 5 . 2 0} \\
(2.40)^{* *}\end{array}$ & $\begin{array}{c}\mathbf{- 3 . 9 9} \\
(2.12)^{*}\end{array}$ & $\begin{array}{c}\mathbf{- 3 . 3 1} \\
(1.286)^{* *}\end{array}$ & $\begin{array}{c}\mathbf{- 3 . 0 2} \\
(1.167)^{* * *}\end{array}$ & $\begin{array}{c}\mathbf{- 2 . 7 8} \\
(0.931)^{* *} \\
\end{array}$ & $\begin{array}{c}\mathbf{- 3 . 1 7} \\
(1.260)^{* *} \\
\end{array}$ & $\begin{array}{c}\mathbf{- 1 . 6 0} \\
(0.735)^{* *}\end{array}$ \\
\hline $\begin{array}{l}\text { Foreign Debt/ } \\
\text { GDP }_{\text {t-1 }}\end{array}$ & $\begin{array}{c}\mathbf{0 . 1 9 6} \\
(0.275) \\
\end{array}$ & $\begin{array}{c}\mathbf{0 . 6 8 7} \\
(0.512) \\
\end{array}$ & $\begin{array}{c}\mathbf{0 . 6 3 7} \\
(0.955) \\
\end{array}$ & $\begin{array}{l}\mathbf{- 0 . 4 7 5} \\
(0.813) \\
\end{array}$ & $\begin{array}{c}\mathbf{0 . 6 6 2} \\
(0.465) \\
\end{array}$ & $\begin{array}{c}\mathbf{0 . 3 5 6} \\
(0.380) \\
\end{array}$ & $\begin{array}{c}\mathbf{0 . 5 0 0} \\
(0.358) \\
\end{array}$ & $\begin{array}{c}\mathbf{0 . 5 3 3} \\
(0.440) \\
\end{array}$ & \\
\hline $\begin{array}{l}\text { Short Term Debt/ } \\
\text { Total Debt }{ }_{\text {t-1 }}\end{array}$ & & $\begin{array}{c}1.51 \\
(1.226)\end{array}$ & $\begin{array}{c}\mathbf{1 . 8 9} \\
(1.779)\end{array}$ & $\begin{array}{l}\mathbf{2 . 7 3 5} \\
(2.22)\end{array}$ & $\begin{array}{c}\mathbf{1 . 7 8} \\
(1.11)\end{array}$ & & $\begin{array}{c}\mathbf{1 . 0 1} \\
(1.01)\end{array}$ & $\begin{array}{c}1.83 \\
(0.984)^{*}\end{array}$ & $\begin{array}{c}\mathbf{0 . 1 9 9} \\
(0.763)\end{array}$ \\
\hline $\begin{array}{l}\text { Liability } \\
\text { Dollarization t-1 } \\
\text { (1) }\end{array}$ & $\begin{array}{c}\mathbf{0 . 5 9 1} \\
(0.256)^{* *}\end{array}$ & $\begin{array}{c}\mathbf{0 . 0 9 4} \\
(0.328)\end{array}$ & & $\begin{array}{c}\mathbf{0 . 6 3 8} \\
(0.448)\end{array}$ & & $\begin{array}{c}\mathbf{0 . 6 8 1} \\
(0.291)^{* *}\end{array}$ & $\begin{array}{c}\mathbf{0 . 1 2 7} \\
(0.299)\end{array}$ & $\begin{array}{c}\mathbf{0 . 2 3 6} \\
(0.314)\end{array}$ & $\begin{array}{c}\mathbf{0 . 2 5 1} \\
(0.231)\end{array}$ \\
\hline $\begin{array}{l}\text { Liability } \\
\text { Dollarization } t-1 \\
(2)\end{array}$ & & & $\begin{array}{l}\mathbf{- 2 . 1 2 6} \\
(1.416)\end{array}$ & & & & & & \\
\hline $\begin{array}{l}\text { Exchange Rate } \\
\text { Rigidity Index t-1 }\end{array}$ & & & & $\begin{array}{c}\mathbf{0 . 3 2 8} \\
(0.146)^{* *} \\
\end{array}$ & & & & & \\
\hline $\begin{array}{l}\text { Current Account/ } \\
\text { GDP }_{t-1}\end{array}$ & $\begin{array}{c}-7.386 \\
(2.06)^{* * *} \\
\end{array}$ & $\begin{array}{c}\mathbf{- 8 . 3 9} \\
(2.50)^{* * *}\end{array}$ & $\begin{array}{c}-\mathbf{- 7 . 6 7 4} \\
(3.755)^{* *} \\
\end{array}$ & $\begin{array}{c}\mathbf{- 1 6 . 8 3} \\
(4.58)^{* * *} \\
\end{array}$ & $\begin{array}{c}\mathbf{- 8 . 4} \\
(2.433)^{* * *} *\end{array}$ & $\begin{array}{c}\mathbf{- 8 . 1 8 6} \\
(2.36)^{* * *}\end{array}$ & $\begin{array}{c}\mathbf{- 7 . 5 7} \\
(2.18)^{* * *}\end{array}$ & $\begin{array}{c}\mathbf{- 8 . 0 4 9} \\
(2.41)^{* * *}\end{array}$ & $\begin{array}{c}\mathbf{- 4 . 6 7} \\
(1.543)^{* *}\end{array}$ \\
\hline FDI/GDP $_{t-1}$ & & & & $\begin{array}{c}\mathbf{- 0 . 0 4 7} \\
(0.1572) \\
\end{array}$ & & & & & \\
\hline $\begin{array}{l}\text { Ln Reserves in } \\
\text { Months of } \\
\text { Imports } t-1 \\
\end{array}$ & & & & $\begin{array}{l}\mathbf{- 0 . 1 7 1} \\
(0.231)\end{array}$ & & & & & \\
\hline $\begin{array}{l}\text { Ln GDP } \\
\text { per capita }_{\text {t-1 }}\end{array}$ & & $\begin{array}{c}\mathbf{0 . 2 3 5} \\
(0.263) \\
\end{array}$ & & $\begin{array}{l}\mathbf{- 0 . 1 6 7} \\
(0.353) \\
\end{array}$ & $\begin{array}{c}\mathbf{0 . 2 0} \\
(0.247) \\
\end{array}$ & $\begin{array}{l}\mathbf{- 0 . 0 3 9} \\
(0.164)\end{array}$ & $\begin{array}{c}\mathbf{0 . 3 9 6} \\
(0.223)^{*} \\
\end{array}$ & & $\begin{array}{c}\mathbf{0 . 2 5 2} \\
(0.159) \\
\end{array}$ \\
\hline $\begin{array}{l}\text { Effectiveness of } \\
\text { Government } t\end{array}$ & & $\begin{array}{c}\mathbf{0 . 1 8 8} \\
(0.287) \\
\end{array}$ & & $\begin{array}{c}\mathbf{0 . 6 3 6} \\
(0.418) \\
\end{array}$ & $\begin{array}{c}\mathbf{0 . 1 9 2} \\
(0.276) \\
\end{array}$ & $\begin{array}{l}\mathbf{- 0 . 2 9 3} \\
(0.247)\end{array}$ & & $\begin{array}{c}\mathbf{0 . 3 1 4} \\
(0.255)\end{array}$ & $\begin{array}{c}\mathbf{0 . 1 6 0} \\
(0.192) \\
\end{array}$ \\
\hline $\begin{array}{c}\text { Regional } \\
\text { Dummies? }\end{array}$ & YES & YES & YES & YES & YES & YES & YES & YES & YES \\
\hline $\begin{array}{c}\text { Year Fixed- } \\
\text { Effects? }\end{array}$ & YES & YES & YES & YES & YES & YES & YES & YES & YES \\
\hline Constant & $\begin{array}{c}\mathbf{- 1 . 7 3} \\
(0.723)^{* *}\end{array}$ & $\begin{array}{c}\mathbf{- 2 . 4 4 3} \\
(1.452)^{*}\end{array}$ & $\begin{array}{c}\mathbf{5 . 8 8} \\
(3.557)\end{array}$ & $\begin{array}{c}\mathbf{- 0 . 3 7 1} \\
(3.099)\end{array}$ & $\begin{array}{c}-\mathbf{2 . 3 3} \\
(1.458)\end{array}$ & $\begin{array}{l}\mathbf{- 0 . 1 3 2} \\
(1.163)\end{array}$ & $\begin{array}{c}\mathbf{- 3 . 6 9 7} \\
(1.501)^{* *}\end{array}$ & $\begin{array}{l}\mathbf{- 1 . 0 8 6} \\
(1.010)\end{array}$ & $\begin{array}{c}\mathbf{- 3 . 0 4} \\
(1.067)^{* *}\end{array}$ \\
\hline Obs. & 1062 & 724 & 262 & 514 & 767 & 934 & 821 & 751 & 1217 \\
\hline
\end{tabular}

Standard errors reported in parenthesis.

$* * *$ Statistically Significant at $1 \%$

** Statistically Significant at 5\%

* Statistically Significant at $10 \%$ 


\section{Table 3: Non-Instrumental variable Probit Regressions}

\begin{tabular}{|c|c|c|c|c|c|c|c|c|c|}
\hline & \multicolumn{9}{|c|}{ Dependent Variable: Crisis Episodes [Frankel and Wei (2004) definition of exchange market pressure] } \\
\hline Trade openness t & $\begin{array}{c}\mathbf{- 0 . 5 7} \\
(0.269)^{* *}\end{array}$ & $\begin{array}{c}\mathbf{- 0 . 6 4} \\
(0.249)^{* *}\end{array}$ & $\begin{array}{l}\mathbf{- 0 . 4 6} \\
0.554\end{array}$ & $\begin{array}{c}\mathbf{- 0 . 5 9} \\
(0.307)^{* *}\end{array}$ & $\begin{array}{c}\mathbf{- 0 . 6 4} \\
(0.262)^{* *}\end{array}$ & $\begin{array}{c}\mathbf{- 0 . 5 8} \\
(0.281)^{* *}\end{array}$ & $\begin{array}{c}\mathbf{- 0 . 3 7} \\
(0.208)^{*}\end{array}$ & $\begin{array}{c}\mathbf{- 0 . 3 2} \\
(0.129)^{* *}\end{array}$ & $\begin{array}{c}\mathbf{- 0 . 5 8} \\
(0.303)^{* *}\end{array}$ \\
\hline $\begin{array}{l}\text { Foreign Debt/ } \\
\text { GDP }_{t-1}\end{array}$ & $\begin{array}{c}\mathbf{0 . 2 3} \\
(0.231) \\
\end{array}$ & $\begin{array}{c}\mathbf{0 . 2 1} \\
(0.196) \\
\end{array}$ & $\begin{array}{c}\mathbf{0 . 3 0} \\
(0.484) \\
\end{array}$ & $\begin{array}{c}\mathbf{0 . 3 1} \\
(0.257) \\
\end{array}$ & $\begin{array}{c}\mathbf{0 . 3 4} \\
(0.209) \\
\end{array}$ & $\begin{array}{c}\mathbf{0 . 2 7} \\
(0.218) \\
\end{array}$ & $\begin{array}{c}\mathbf{0 . 3 5} \\
(0.176)^{* *} \\
\end{array}$ & & $\begin{array}{c}\mathbf{0 . 2 4} \\
(0.233) \\
\end{array}$ \\
\hline $\begin{array}{l}\text { Short Term Debt/ } \\
\text { Total Debt t-1 }\end{array}$ & & $\begin{array}{c}\mathbf{0 . 3 9} \\
(0.694)\end{array}$ & & & $\begin{array}{c}\text { 0.30 } \\
(0.711)\end{array}$ & & & & $\begin{array}{c}\mathbf{0 . 8 3} \\
(0.877)\end{array}$ \\
\hline $\begin{array}{l}\text { Liability } \\
\text { Dollarization t-1 } \\
\text { (1) }\end{array}$ & $\begin{array}{c}\mathbf{0 . 0 2 7} \\
(0.249)\end{array}$ & $\begin{array}{c}\mathbf{0 . 0 6 2} \\
(0.224)\end{array}$ & & $\begin{array}{c}\mathbf{0 . 0 2 4} \\
(0.288)\end{array}$ & & & $\begin{array}{c}\mathbf{0 . 0 4 4} \\
(0.205)\end{array}$ & $\begin{array}{c}\mathbf{- 0 . 0 0 0 3} \\
(0.148)\end{array}$ & \\
\hline $\begin{array}{l}\text { Liability } \\
\text { Dollarization t-1 } \\
\text { (2) }\end{array}$ & & & $\begin{array}{l}\mathbf{- 1 . 0} \\
1.76\end{array}$ & & & & & & \\
\hline $\begin{array}{l}\text { Exchange Rate } \\
\text { Rigidity Index t-1 }\end{array}$ & $\begin{array}{c}\mathbf{0 . 1 3} \\
(0.094)\end{array}$ & & & $\begin{array}{c}\mathbf{0 . 1 8} \\
(0.098)^{* *}\end{array}$ & $\begin{array}{c}\mathbf{0 . 1 5} \\
(0.090)^{*}\end{array}$ & $\begin{array}{c}\mathbf{0 . 1 4} \\
(0.097)\end{array}$ & & & $\begin{array}{c}\mathbf{0 . 1 5} \\
(0.103)\end{array}$ \\
\hline $\begin{array}{l}\text { Current Account/ } \\
\text { GDP }_{t-1}\end{array}$ & $\begin{array}{l}-\mathbf{0 . 2 7 2} \\
(1.392)\end{array}$ & $\begin{array}{c}\mathbf{0 . 0 0 4} \\
(1.406)\end{array}$ & & $\begin{array}{l}\mathbf{- 0 . 9 5} \\
(1.54)\end{array}$ & & & & & $\begin{array}{c}\mathbf{0 . 5 5} \\
(1.381)\end{array}$ \\
\hline FDI/GDP ${ }_{t-1}$ & & & & $\begin{array}{c}\mathbf{0 . 0 3} \\
(0.058)\end{array}$ & & & & & $\begin{array}{c}\mathbf{0 . 0 3} \\
(0.032)\end{array}$ \\
\hline $\begin{array}{l}\text { Ln Reserves in } \\
\text { Months of } \\
\text { Imports }_{t-1}\end{array}$ & $\begin{array}{c}\mathbf{- 0 . 2 6} \\
(0.082)^{* * * *}\end{array}$ & $\begin{array}{c}\mathbf{- 0 . 3 0} \\
(0.079)^{* *}\end{array}$ & $\begin{array}{c}\mathbf{- 0 . 3 5} \\
(0.3851)\end{array}$ & $\begin{array}{c}\mathbf{- 0 . 1 9} \\
(0.087)^{* *}\end{array}$ & $\begin{array}{c}\mathbf{- 0 . 2 2} \\
(0.069)^{* * *} *\end{array}$ & $\begin{array}{c}\mathbf{- 0 . 2 5} \\
(0.077)^{* * *}\end{array}$ & & $\begin{array}{c}\mathbf{- 0 . 2 1} \\
(0.036)^{* * *}\end{array}$ & $\begin{array}{c}\mathbf{- 0 . 2 9} \\
(0.083)^{* * * *}\end{array}$ \\
\hline $\begin{array}{l}\text { Ln GDP } \\
\text { per capita }_{t-1}\end{array}$ & & & & & & $\begin{array}{c}\mathbf{0 . 0 0 9} \\
(0.1114)\end{array}$ & & & $\begin{array}{l}\mathbf{- 0 . 0 5 8} \\
(0.139)\end{array}$ \\
\hline $\begin{array}{l}\text { Effectiveness of } \\
\text { Government }{ }_{t}\end{array}$ & & $\begin{array}{c}\mathbf{0 . 0 9} \\
(0.152)\end{array}$ & & & $\begin{array}{c}\mathbf{0 . 1 7} \\
(0.153)\end{array}$ & $\begin{array}{c}\mathbf{0 . 2 5} \\
(0.158)\end{array}$ & & & $\begin{array}{c}\mathbf{0 . 2 5} \\
(0.172)\end{array}$ \\
\hline $\begin{array}{c}\text { Regional } \\
\text { Dummies? }\end{array}$ & YES & YES & YES & YES & YES & YES & YES & YES & YES \\
\hline $\begin{array}{l}\text { Year Fixed- } \\
\text { Effects? }\end{array}$ & YES & YES & YES & YES & YES & YES & YES & YES & YES \\
\hline Constant & $\begin{array}{c}\mathbf{- 0 . 9 9} \\
(0.749)\end{array}$ & $\begin{array}{l}\mathbf{- 0 . 0 0 9} \\
(0.562)\end{array}$ & $\begin{array}{c}\mathbf{0 . 5 6 5} \\
(1.041)\end{array}$ & $\begin{array}{c}\mathbf{- 0 . 5 8 1} \\
(1.085)\end{array}$ & $\begin{array}{c}\mathbf{- 0 . 4 8 6} \\
(0.568)\end{array}$ & $\begin{array}{c}\mathbf{- 0 . 5 3 1} \\
(1.069)^{* *}\end{array}$ & $\begin{array}{c}\mathbf{- 1 . 4 4 7} \\
(0.61)^{* *}\end{array}$ & $\begin{array}{l}\mathbf{- 0 . 5 9 9} \\
(0.498)\end{array}$ & $\begin{array}{c}\mathbf{- 0 . 4 6 1} \\
(0.958)\end{array}$ \\
\hline Obs. & 557 & 690 & 119 & 481 & 622 & 586 & 798 & 1841 & 561 \\
\hline $\mathbf{R}^{2}$ & 0.1186 & 0.1252 & 0.2113 & 0.1201 & 0.1253 & 0.1211 & 0.0894 & 0.0857 & 0.1238 \\
\hline
\end{tabular}

Robust standard errors reported in parenthesis.

*** Statistically Significant at $1 \%$

** Statistically Significant at 5\%

* Statistically Significant at $10 \%$ 
Table 4: Probit Instrumental Variables Regressions

\begin{tabular}{|c|c|c|c|c|c|c|c|c|c|}
\hline & \multicolumn{9}{|c|}{ Dependent Variable: Crisis Episodes [Frankel and Wei (2004) definition of exchange market pressure] } \\
\hline Trade openness $t$ & $\begin{array}{c}\mathbf{- 1 . 7 3} \\
(0.918)^{*} \\
\end{array}$ & $\begin{array}{c}\mathbf{- 1 . 6 2} \\
(0.747)^{* *}\end{array}$ & $\begin{array}{c}\mathbf{- 2 . 5 3} \\
(2.518) \\
\end{array}$ & $\begin{array}{c}\mathbf{- 1 . 9 5} \\
(1.045)^{*}\end{array}$ & $\begin{array}{c}\mathbf{- 1 . 5 3} \\
(0.765)^{* *}\end{array}$ & $\begin{array}{c}\mathbf{- 1 . 7 7} \\
(0.946)^{*}\end{array}$ & $\begin{array}{c}\mathbf{- 0 . 9 7} \\
(0.591)^{*}\end{array}$ & $\begin{array}{c}\mathbf{- 1 . 0 6} \\
(0.393)^{* *}\end{array}$ & $\begin{array}{c}\mathbf{- 2 . 0 7} \\
(1.025)^{*}\end{array}$ \\
\hline $\begin{array}{l}\text { Foreign Debt/ } \\
\text { GDP }_{\text {t-1 }}\end{array}$ & $\begin{array}{c}\mathbf{0 . 5 9} \\
(0.373) \\
\end{array}$ & $\begin{array}{c}\mathbf{0 . 4 9} \\
(0.274)^{*} \\
\end{array}$ & $\begin{array}{c}\mathbf{- 0 . 1 7} \\
(0.786) \\
\end{array}$ & $\begin{array}{c}\mathbf{0 . 7 5 6} \\
(0.422)^{*} \\
\end{array}$ & $\begin{array}{c}\mathbf{0 . 6 5 3} \\
(0.334)^{*} \\
\end{array}$ & $\begin{array}{c}\mathbf{0 . 6 1 6} \\
(0.35)^{*} \\
\end{array}$ & $\begin{array}{c}\mathbf{0 . 5 7 1} \\
(0.227)^{* *} \\
\end{array}$ & & $\begin{array}{c}\mathbf{0 . 7 5} \\
(0.416)^{*} \\
\end{array}$ \\
\hline $\begin{array}{l}\text { Short Term Debt/ } \\
\text { Total Debt t-1 }\end{array}$ & & $\begin{array}{c}\mathbf{0 . 3 9} \\
(0.672)\end{array}$ & & & $\begin{array}{c}\mathbf{0 . 3 2} \\
(0.677)\end{array}$ & & & & $\begin{array}{c}\mathbf{0 . 7 5} \\
(0.914)\end{array}$ \\
\hline $\begin{array}{l}\text { Liability } \\
\text { Dollarization t-1 } \\
\text { (1) }\end{array}$ & $\begin{array}{c}\mathbf{0 . 1 8} \\
(0.234)\end{array}$ & $\begin{array}{c}\mathbf{0 . 0 5} \\
(0.217)\end{array}$ & & $\begin{array}{c}\mathbf{0 . 2 1} \\
(0.274)\end{array}$ & & & $\begin{array}{c}\mathbf{- 0 . 1 1} \\
(0.181)\end{array}$ & $\begin{array}{c}\mathbf{0 . 0 0 1} \\
(0.143)\end{array}$ & $\begin{array}{c}\mathbf{0 . 0 1 5} \\
(0.290)\end{array}$ \\
\hline $\begin{array}{l}\text { Liability } \\
\text { Dollarization } t-1 \\
(2)\end{array}$ & & & $\begin{array}{c}\mathbf{- 1 . 4 2} \\
(2.679)\end{array}$ & & & & & & \\
\hline $\begin{array}{l}\text { Exchange Rate } \\
\text { Rigidity Index t-1 }\end{array}$ & $\begin{array}{c}\mathbf{0 . 2 2} \\
(0.113)^{*}\end{array}$ & & & $\begin{array}{c}\mathbf{0 . 2 6} \\
(0.116)^{* *} \\
\end{array}$ & $\begin{array}{c}\mathbf{0 . 1 9} \\
(0.099)^{* *} \\
\end{array}$ & $\begin{array}{c}\mathbf{0 . 2 6} \\
(0.128)^{* *} \\
\end{array}$ & & & $\begin{array}{c}\mathbf{0 . 2 7} \\
(0.125)^{* *} \\
\end{array}$ \\
\hline $\begin{array}{l}\text { Current Account/ } \\
\text { GDP }_{t-1}\end{array}$ & $\begin{array}{c}\mathbf{0 . 6 6} \\
(1.455) \\
\end{array}$ & $\begin{array}{c}\mathbf{0 . 9 1} \\
(1.37) \\
\end{array}$ & & $\begin{array}{c}\mathbf{0 . 3 4} \\
(1.677) \\
\end{array}$ & & & & & $\begin{array}{c}\mathbf{0 . 2 1} \\
(1.72) \\
\end{array}$ \\
\hline FDI/GDP $_{t-1}$ & & & & $\begin{array}{c}\mathbf{0 . 1 3} \\
(0.098) \\
\end{array}$ & & & & & $\begin{array}{c}\mathbf{0 . 1 3} \\
(0.088) \\
\end{array}$ \\
\hline $\begin{array}{l}\text { Ln Reserves in } \\
\text { Months of } \\
\text { Imports }_{t-1}\end{array}$ & $\begin{array}{c}\mathbf{- 0 . 3 7} \\
(0.099)^{* * *} *\end{array}$ & $\begin{array}{c}\mathbf{- 0 . 3 9} \\
(0.089)^{* * *}\end{array}$ & $\begin{array}{c}\mathbf{- 0 . 8 3} \\
(0.619)\end{array}$ & $\begin{array}{c}\mathbf{- 0 . 3 0} \\
(0.11)^{* *}\end{array}$ & $\begin{array}{c}\mathbf{- 0 . 2 6} \\
(0.078)^{* * *}\end{array}$ & $\begin{array}{c}\mathbf{- 0 . 3 7} \\
(0.110)^{* * *}\end{array}$ & & $\begin{array}{c}\mathbf{- 0 . 2 9} \\
(0.0436)^{* *}\end{array}$ & $\begin{array}{c}\mathbf{- 0 . 3 0} \\
(0.106)^{* *}\end{array}$ \\
\hline $\begin{array}{l}\text { Ln GDP } \\
\text { per capita }_{\text {t-1 }}\end{array}$ & & & & & & $\begin{array}{c}\mathbf{0 . 0 4} \\
(0.104) \\
\end{array}$ & & & \\
\hline $\begin{array}{l}\text { Effectiveness of } \\
\text { Government }{ }_{t}\end{array}$ & & $\begin{array}{c}\mathbf{0 . 1 3} \\
(0.161)\end{array}$ & & & $\begin{array}{c}\mathbf{0 . 1 9 6} \\
(0.159) \\
\end{array}$ & $\begin{array}{c}\mathbf{0 . 2 7} \\
(0.165)\end{array}$ & & & $\begin{array}{c}\mathbf{0 . 3 5} \\
(0.203)\end{array}$ \\
\hline $\begin{array}{c}\text { Regional } \\
\text { Dummies? }\end{array}$ & YES & YES & YES & YES & YES & YES & YES & YES & YES \\
\hline $\begin{array}{c}\text { Year Fixed- } \\
\text { Effects? }\end{array}$ & YES & YES & YES & YES & YES & YES & YES & YES & YES \\
\hline Constant & $\begin{array}{c}\mathbf{0 . 3 0 4} \\
(0.786)\end{array}$ & $\begin{array}{l}\mathbf{- 0 . 3 9 2} \\
(0.089)\end{array}$ & $\begin{array}{c}\mathbf{2 . 8 2} \\
(2.667)\end{array}$ & $\begin{array}{c}\mathbf{0 . 4 7 2} \\
(0.982)\end{array}$ & $\begin{array}{c}\mathbf{0 . 1 3 9} \\
(0.764)\end{array}$ & $\begin{array}{l}\mathbf{- 1 . 3 6 4} \\
(0.89) \\
\end{array}$ & $\begin{array}{l}\mathbf{- 1 . 0 3 5} \\
(0.576)\end{array}$ & $\begin{array}{l}\mathbf{- 0 . 6 8 4} \\
(0.572)\end{array}$ & $\begin{array}{l}\mathbf{- 0 . 1 4 7} \\
(1.10) \\
\end{array}$ \\
\hline Obs. & 841 & 841 & 331 & 738 & 737 & 1038 & 1196 & 2375 & 580 \\
\hline
\end{tabular}

Standard errors reported in parenthesis.

*** Statistically Significant at $1 \%$

** Statistically Significant at 5\%

* Statistically Significant at $10 \%$ 


\section{Appendixes}

\section{A.1 Sudden Stops}

I use four alternative definitions of sudden stops: my preferred definition "SS 1", and three alternative "SS2", "SS3" and "SS4". "SS2" and "SS3" are conceptually equivalent to "SS1", but are more restrictive in that they capture fewer episodes. "SS4" is, instead, equivalent to "SS1" but is less restrictive in that classifies as sudden stops events that don't necessarily trigger recessions.

Algorithm used to compute "Sudden Stop 1" (SS1):

1) Use IFS Financial Account Data (Line 78B) annual data for all available countries in the period 1970-2002.

2) Compute the standard deviation of observations for each decade (70's, 80's, 90's+) in the sample and then compute the mean standard deviation for by averaging the results obtained for each decade.

3) Compute the year to year changes in the financial account (FA) for all countries in the sample. Unavailable data points are classified as "n.a."

4) Filter to keep observations (country/year) that show reductions in the financial account between years " $t$ " and " $t-1$ " if at " $t-1$ " FA was in surplus (i.e. keep only observations that show reductions in FA surpluses). Observations that don't pass this filter, because they show either a year-to-year increase in the FA; or a year-toyear reduction in an outstanding FA deficit are classified as " 0 ".

5) Filter again to keep (out of the observations already filtered in step (4)) only those that represent a reduction in the FA surplus that is above 2 standard deviations from the mean standard deviation computed in step (2). Observations that don't pass this filter are classified as " 0 " adding to the " 0 's" from step (4).

6) Filter again to keep only those observations that are accompanied by a fall in GDP per capita in that country during the same year or the year immediately after. Observations that don't pass this filter are classified as " 0 " adding to the " 0 ' $s$ " from steps (4) and (5)

7) Filter again to keep only those that are accompanied by a fall in the current account deficit in that country during the same year or the year immediately after. Observations that don't pass this filter are classified as " 0 " adding to the " 0 ' $s$ " from steps (4), (5) and (6).

8) Classify the observations that survive all filters as " 1 " indicating that they represent episodes (country/year) when SS took place. The other observations are classified as either "0" which means no episodes were registered during that year in that country, or "n.a" which means that some data is missing.

9) Results:

Number of Observations in the Dataset

\begin{tabular}{|c|c|c|}
\hline “1” sudden stop & “0” no episode & “n.a.” no data \\
\hline 86 & 3510 & 1651 \\
\hline
\end{tabular}


Algorithm used to compute "Sudden Stop 2" (SS2):

1) Use IFS Financial Account Data (Line 78B) annual data for all available countries in the period 1970-2002.

2) Compute the standard deviation of observations for each decade (70's, 80's, 90's+) in the sample.

3) Compute the year to year changes in the financial account (FA) for all countries in the sample. Unavailable data points are classified as "n.a."

4) Filter to keep observations (country/year) that show reductions in the financial account between years " $\mathrm{t}$ " and " $\mathrm{t}-1$ " if at " $\mathrm{t}-1$ " FA was in surplus (i.e. keep only observations that show reductions in FA surpluses). Observations that don't pass this filter, because they show either a year-to-year increase in the FA; or a year-toyear reduction in an outstanding FA deficit are classified as " 0 ".

5) Filter again to keep (out of the observations already filtered in step (4)) only those that represent a reduction in the FA surplus that is above 2 standard deviations from the corresponding decade standard deviation computed in step (2). Observations that don't pass this filter are classified as " 0 " adding to the " 0 's" from step (4).

6) Filter again to keep only those observations that are accompanied by a fall in GDP per capita in that country during the same year or the year immediately after. Observations that don't pass this filter are classified as " 0 " adding to the " 0 ' $s$ " from steps (4) and (5)

7) Filter again to keep only those that are accompanied by a fall in the current account deficit in that country during the same year or the year immediately after. Observations that don't pass this filter are classified as " 0 " adding to the " 0 's" from steps (4), (5) and (6).

8) Classify the observations that survive all filters as " 1 " indicating that they represent episodes (country/year) when SS took place. The other observations are classified as either " 0 " which means no episodes were registered during that year in that country, or "n.a" which means that some data is missing.

9) Results:

Number of Observations in the Dataset

\begin{tabular}{|c|c|c|}
\hline “1” sudden stop & “0” no episode & "n.a.” no data \\
\hline 68 & 3531 & 1648 \\
\hline
\end{tabular}


Algorithm used to compute "Sudden Stop 3" (SS3):

1) Use IFS Financial Account Data (Line 78B) annual data for all available countries in the period 1970-2002.

2) Compute the year to year changes in the financial account (FA) for all countries in the sample. Unavailable data points are classified as "n.a."

3) Compute the standard deviation the year to year changes for each decade (70's, 80 's, 90's+) in the sample and then compute the mean standard deviation for by averaging the results obtained for each decade

4) Filter to keep observations (country/year) that show reductions in the financial account between years " $\mathrm{t}$ " and "t-1" if at "t-1" FA was in surplus (i.e. keep only observations that show reductions in FA surpluses). Observations that don't pass this filter, because they show either a year-to-year increase in the FA; or a year-toyear reduction in an outstanding FA deficit are classified as " 0 ".

5) Filter again to keep (out of the observations already filtered in step (4)) only those that represent a reduction in the FA surplus that is above 2 standard deviations from the mean standard deviation computed in step (3). Observations that don't pass this filter are classified as "0" adding to the "0's" from step (4).

6) Filter again to keep only those observations that are accompanied by a fall in GDP per capita in that country during the same year or the year immediately after. Observations that don't pass this filter are classified as " 0 " adding to the " 0 's" from steps (4) and (5)

7) Filter again to keep only those that are accompanied by a fall in the current account deficit in that country during the same year or the year immediately after. Observations that don't pass this filter are classified as " 0 " adding to the " 0 's" from steps (4), (5) and (6).

8) Classify the observations that survive all filters as " 1 " indicating that they represent episodes (country/year) when SS took place. The other observations are classified as either " 0 " which means no episodes were registered during that year in that country, or "n.a" which means that some data is missing.

9) Results:

Number of Observations in the Dataset

\begin{tabular}{|c|c|c|}
\hline “'” sudden stop & “0” no episode & "n.a.” no data \\
\hline 48 & 3551 & 1648 \\
\hline
\end{tabular}


Algorithm used to compute "Sudden Stop 4" (SS4):

1) Use IFS Financial Account Data (Line 78B) annual data for all available countries in the period 1970-2002.

2) Compute the standard deviation of observations for each decade (70's, 80's, 90's+) in the sample and then compute the mean standard deviation for by averaging the results obtained for each decade.

3) Compute the year to year changes in the financial account (FA) for all countries in the sample. Unavailable data points are classified as "n.a."

4) Filter to keep observations (country/year) that show reductions in the financial account between years " $\mathrm{t}$ " and "t-1" if at "t-1" FA was in surplus (i.e. keep only observations that show reductions in FA surpluses). Observations that don't pass this filter, because they show either a year-to-year increase in the FA; or a year-toyear reduction in an outstanding FA deficit are classified as " 0 ".

5) Filter again to keep (out of the observations already filtered in step (4)) only those that represent a reduction in the FA surplus that is above 2 standard deviations from the mean standard deviation computed in step (2). Observations that don't pass this filter are classified as "0" adding to the "0's" from step (4).

6) Filter again to keep only those that are accompanied by a fall in the current account deficit in that country during the same year or the year immediately after. Observations that don't pass this filter are classified as " 0 " adding to the " 0 's" from steps (4), (5) and (6).

7) Classify the observations that survive all filters as " 1 " indicating that they represent episodes (country/year) when SS took place. The other observations are classified as either " 0 " which means no episodes were registered during that year in that country, or "n.a" which means that some data is missing.

8) Results:

Number of Observations in the Dataset

\begin{tabular}{|c|c|c|}
\hline “1” sudden stop & “0” no episode & “n.a.” no data \\
\hline 145 & 3450 & 1652 \\
\hline
\end{tabular}


Table A.1: Sudden Stops 1

\begin{tabular}{|c|c|c|c|c|c|}
\hline Country & $\begin{array}{l}\text { Number of } \\
\text { Episodes }\end{array}$ & & & & \\
\hline Afghanistan, I.S. of & 0 & & & & \\
\hline Albania & 0 & & & & \\
\hline Algeria & 1 & 1990 & & & \\
\hline Angola & 0 & & & & \\
\hline Antigua and Barbuda & 0 & & & & \\
\hline Argentina & 1 & 2001 & & & \\
\hline Aruba & 0 & & & & \\
\hline Australia & 0 & & & & \\
\hline Austria & 0 & & & & \\
\hline Bahamas, The & 0 & & & & \\
\hline Bahrain, Kingdom of & 0 & & & & \\
\hline Bangladesh & 0 & & & & \\
\hline Barbados & 1 & 1982 & & & \\
\hline Belgium & 0 & & & & \\
\hline Belgium-Luxembourg & 0 & & & & \\
\hline Belize & 0 & & & & \\
\hline Benin & 1 & 1983 & & & \\
\hline Bolivia & 1 & 1982 & & & \\
\hline Bosnia \& Herzegovina & 0 & & & & \\
\hline Botswana & 0 & & & & \\
\hline Brazil & 0 & & & & \\
\hline Bulgaria & 0 & & & & \\
\hline Burkina Faso & 1 & 1989 & & & \\
\hline Burundi & 0 & & & & \\
\hline Cambodia & 0 & & & & \\
\hline Cameroon & 2 & 1988 & 1990 & & \\
\hline Canada & 1 & 1982 & & & \\
\hline Cape Verde & 1 & 1990 & & & \\
\hline Central African Rep. & 1 & 1988 & & & \\
\hline Chad & 0 & & & & \\
\hline Chile & 3 & 1982 & 1983 & 1998 & \\
\hline China,P.R.: Mainland & 0 & & & & \\
\hline China,P.R.:Hong Kong & 0 & & & & \\
\hline Colombia & 2 & 1998 & 1999 & & \\
\hline Comoros & 1 & 1988 & & & \\
\hline Congo, Republic of & 2 & 1984 & 1996 & & \\
\hline Costa Rica & 2 & 1981 & 1996 & & \\
\hline Côte d'Ivoire & 0 & & & & \\
\hline Croatia & 0 & & & & \\
\hline Cyprus & 0 & & & & \\
\hline Czech Republic & 0 & & & & \\
\hline Czechoslovakia & 0 & & & & \\
\hline Denmark & 0 & & & & \\
\hline Djibouti & 0 & & & & \\
\hline Dominica & 1 & 2001 & & & \\
\hline
\end{tabular}




\begin{tabular}{|c|c|c|c|c|c|}
\hline Dominican Republic & 0 & & & & \\
\hline Ecuador & 2 & 1983 & 1999 & & \\
\hline Egypt & 1 & 1990 & & & \\
\hline El Salvador & 1 & 1979 & & & \\
\hline Equatorial Guinea & 0 & & & & \\
\hline Ethiopia & 2 & 1982 & 1991 & & \\
\hline Fiji & 1 & 1999 & & & \\
\hline Finland & 1 & 1991 & & & \\
\hline France & 0 & & & & \\
\hline Gabon & 0 & & & & \\
\hline Gambia, The & 1 & 1982 & & & \\
\hline Germany & 1 & 2001 & & & \\
\hline Ghana & 0 & & & & \\
\hline Greece & 0 & & & & \\
\hline Grenada & 0 & & & & \\
\hline Guatemala & 0 & & & & \\
\hline Guinea & 0 & & & & \\
\hline Guinea-Bissau & 1 & 1986 & & & \\
\hline Guyana & 0 & & & & \\
\hline Haiti & 0 & & & & \\
\hline Honduras & 0 & & & & \\
\hline Hungary & 0 & & & & \\
\hline Iceland & 1 & 2001 & & & \\
\hline India & 0 & & & & \\
\hline Indonesia & 1 & 1997 & & & \\
\hline Iran, I.R. of & 0 & & & & \\
\hline Iraq & 0 & & & & \\
\hline Ireland & 0 & & & & \\
\hline Israel & 2 & 1988 & 1998 & & \\
\hline Italy & 0 & & & & \\
\hline Jamaica & 0 & & & & \\
\hline Japan & 0 & & & & \\
\hline Jordan & 2 & 1992 & 1993 & & \\
\hline Kenya & 0 & & & & \\
\hline Kiribati & 0 & & & & \\
\hline Korea & 1 & 1997 & & & \\
\hline Kuwait & 0 & & & & \\
\hline Kyrgyz Republic & 0 & & & & \\
\hline Lao People's Dem.Rep & 0 & & & & \\
\hline Lesotho & 0 & & & & \\
\hline Liberia & 0 & & & & \\
\hline Libya & 0 & & & & \\
\hline Macedonia, FYR & 0 & & & & \\
\hline Madagascar & 0 & & & & \\
\hline Malawi & 1 & 1981 & & & \\
\hline Malaysia & 1 & 1997 & & & \\
\hline Maldives & 0 & & & & \\
\hline Mali & 0 & & & & \\
\hline Malta & 1 & 2000 & & & \\
\hline
\end{tabular}




\begin{tabular}{|c|c|c|c|c|c|}
\hline Mauritania & 0 & & & & \\
\hline Mauritius & 0 & & & & \\
\hline Mexico & 3 & 1982 & 1994 & 1995 & \\
\hline Mongolia & 2 & 1990 & 1991 & & \\
\hline Montserrat & 0 & & & & \\
\hline Morocco & 1 & 1995 & & & \\
\hline Mozambique & 0 & & & & \\
\hline Myanmar & 0 & & & & \\
\hline Namibia & 0 & & & & \\
\hline Nepal & 0 & & & & \\
\hline Netherlands & 1 & 1981 & & & \\
\hline Netherlands Antilles & 0 & & & & \\
\hline New Zealand & 2 & 1988 & 1998 & & \\
\hline Nicaragua & 1 & 1986 & & & \\
\hline Niger & 0 & & & & \\
\hline Nigeria & 1 & 1999 & & & \\
\hline Norway & 0 & & & & \\
\hline Oman & 2 & 1987 & 1999 & & \\
\hline Pakistan & 0 & & & & \\
\hline Panama & 1 & 2000 & & & \\
\hline Papua New Guinea & 0 & & & & \\
\hline Paraguay & 1 & 2002 & & & \\
\hline Peru & 1 & 1998 & & & \\
\hline Philippines & 2 & 1997 & 1998 & & \\
\hline Poland & 0 & & & & \\
\hline Portugal & 1 & 1992 & & & \\
\hline Romania & 0 & & & & \\
\hline Rwanda & 1 & 1994 & & & \\
\hline Samoa & 0 & & & & \\
\hline São Tomé \& Príncipe & 0 & & & & \\
\hline Saudi Arabia & 0 & & & & \\
\hline Senegal & 0 & & & & \\
\hline Seychelles & 1 & 2000 & & & \\
\hline Sierra Leone & 0 & & & & \\
\hline Singapore & 0 & & & & \\
\hline Slovak Republic & 0 & & & & \\
\hline Slovenia & 0 & & & & \\
\hline Solomon Islands & 1 & 1998 & & & \\
\hline Somalia & 0 & & & & \\
\hline South Africa & 0 & & & & \\
\hline Spain & 1 & 1992 & & & \\
\hline Sri Lanka & 1 & 2001 & & & \\
\hline St. Kitts and Nevis & 0 & & & & \\
\hline St. Lucia & 1 & 2001 & & & \\
\hline St. Vincent \& Grens. & 1 & 2000 & & & \\
\hline Sudan & 0 & & & & \\
\hline Suriname & 1 & 1992 & & & \\
\hline Swaziland & 1 & 1999 & & & \\
\hline Sweden & 1 & 1991 & & & \\
\hline
\end{tabular}




\begin{tabular}{|l|l|l|l|l|l|}
\hline Switzerland & 0 & & & & \\
\hline Syrian Arab Republic & 1 & 1989 & & & \\
\hline Tanzania & 0 & & & & \\
\hline Thailand & 1 & 1997 & & & \\
\hline Togo & 0 & & & & \\
\hline Tonga & 1 & 1989 & & & \\
\hline Trinidad and Tobago & 1 & 1984 & & & \\
\hline Tunisia & 0 & & & & \\
\hline Turkey & 4 & 1991 & 1994 & 1998 & 2001 \\
\hline Uganda & 0 & & & & \\
\hline United Kingdom & 0 & & & & \\
\hline United States & 0 & & & & \\
\hline Uruguay & 1 & 2002 & & & \\
\hline Vanuatu & 1 & 1991 & & & \\
\hline Venezuela, Rep. Bol. & 1 & 1994 & & & \\
\hline Vietnam & 0 & & & & \\
\hline Yemen, Republic of & 1 & 1994 & & & \\
\hline Zambia & 1 & 1990 & & & \\
\hline Zimbabwe & & & & & \\
\hline
\end{tabular}




\section{A.2. Gravity Estimates}

To compute the gravity estimates we use Frankel and Rose (2002) dataset. It consists of 41,678 bilateral trade observations spanning six different years (1970, 1975, 1980, 1985, 1990, and 1995). All 186 countries, dependencies, territories, overseas departments, colonies, and so forth for which the United Nations Statistical Office collects international trade data are included in the data set. The trade data are taken from the World Trade Database, a consistent recompilation of the U.N. trade data presented in Feenstra, Lipsey, and Bowen (1997), augmented with data from U.N.'s International Trade Statistics Yearbook. This data set is estimated to cover at least $98 \%$ of all trade.

For each of the six different years for which I have data I compute OLS regressions of the following form:

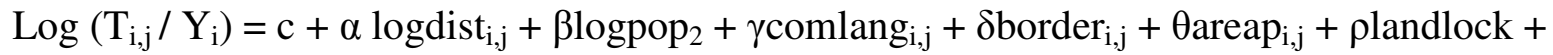
$\mu$

Where " $T_{i, j}$ " is the bilateral trade value between countries " $i$ " and " $j$ "; "Y $Y_{i}$ " is the real GDP of country "i"; "c" is a constant term; "logdist $t_{i, j}$ " is the log of the distance between the economic centers of countries "i" and " $\mathrm{j}$ "; "comlang" is a dummy variable that takes value one if " $\mathrm{i}$ " and " $\mathrm{j}$ " share a common language and is zero otherwise; "border" is a dummy variable that takes value one if " $\mathrm{i}$ " and " $\mathrm{j}$ " share a border and is zero otherwise; "areap $\mathrm{p}_{\mathrm{i}, \mathrm{j}}$ " is the $\log$ of the product of the areas (in $\mathrm{km}^{2}$ ) of countries "i" and " $\mathrm{j}$ "; and "landlock" takes values two if " $i$ " and " $j$ " are both landlocked, one if either " $\mathrm{i}$ " or " $\mathrm{j}$ " are landlocked, and zero otherwise; and " $\mu$ " is the error term.

The gravity estimates are generated by taking the exponent of fitted values and summing across bilateral partners $\mathrm{j}$. This yields estimates for six different years: 1970, 1975, 1980, 1985, 1990 and 1995. The missing values of the panel are generated by taking the observation corresponding to the closest year with data. The correlation between trade ratio and generated IV for the entire panel is 0.52 . 
A.3. Summary Statistics and Data Sources

\begin{tabular}{|c|c|c|c|c|c|}
\hline Variable & Obs. & Mean & Std. Dev. & Min & Max \\
\hline SS1 & 3596 & .0239155 & .1528071 & 0 & 1 \\
\hline $\begin{array}{l}\text { SS1bis (no contiguous } \\
\text { crises) }\end{array}$ & 3590 & .0222841 & .1476266 & 0 & 1 \\
\hline SS2 & 3599 & .0188941 & .1361701 & 0 & 1 \\
\hline $\begin{array}{l}\text { SS2bis (no contiguous } \\
\text { crises) }\end{array}$ & 3596 & .0180756 & .1332436 & 0 & 1 \\
\hline SS3 & 3599 & .013337 & .1147293 & 0 & 1 \\
\hline $\begin{array}{l}\text { SS3bis (no contiguous } \\
\text { crises) }\end{array}$ & 3597 & .0127884 & .1123762 & 0 & 1 \\
\hline SS4 & 3595 & .0403338 & .1967683 & 0 & 1 \\
\hline $\begin{array}{l}\text { SS4bis (no contiguous } \\
\text { crises) }\end{array}$ & 3587 & .0381935 & .1916898 & 0 & 1 \\
\hline Trade openness & 4247 & .7322445 & .432648 & .0153068 & 2.960163 \\
\hline Fitted trade openness (B) & 4261 & .1487951 & .1497813 & .0016543 & 1.364657 \\
\hline $\begin{array}{l}\text { Lagged } \\
\text { Dollarization (1) }\end{array}$ & 3454 & .3207969 & .3902904 & 0 & 1.999936 \\
\hline $\begin{array}{l}\text { Lagged } \\
\text { Dollarization (2) }\end{array}$ & 897 & .2666019 & .2752479 & 0 & 1 \\
\hline $\begin{array}{l}\text { Lagged ratio of foreign debt } \\
\text { to GDP }\end{array}$ & 1789 & .2780933 & .4375788 & 0 & 5.844839 \\
\hline
\end{tabular}




\begin{tabular}{|c|c|c|c|c|c|}
\hline $\begin{array}{l}\text { Lagged current account } \\
\text { balance to GDP }\end{array}$ & 3630 & -.038277 & .1034782 & -2.404958 & .58553 \\
\hline $\begin{array}{l}\text { Lagged ratio of foreign debt } \\
\text { to GDP }\end{array}$ & 1791 & .2779454 & .4373619 & 0 & 5.844839 \\
\hline $\begin{array}{l}\text { Lagged index of exchange } \\
\text { rate rigidity }\end{array}$ & 3059 & 2.411246 & .8072297 & 1 & 3 \\
\hline $\begin{array}{l}\text { Voice and } \\
\text { Accountability }\end{array}$ & 3255 & .3525906 & .9023457 & -1.623367 & 1.693636 \\
\hline $\begin{array}{l}\text { Political Stability/Lack of } \\
\text { Violence }\end{array}$ & 3038 & .2303492 & .8255066 & -1.694225 & 1.69047 \\
\hline $\begin{array}{l}\text { Effectiveness of } \\
\text { Government }\end{array}$ & 3038 & .3136892 & .8409723 & -1.320767 & 2.082198 \\
\hline Regulatory Framework (I) & 3224 & .3598345 & .5851707 & -1.500832 & 1.244778 \\
\hline Rule of Law & 3224 & .2939932 & .871838 & -1.203638 & 1.995832 \\
\hline Control of Corruption (I) & 3038 & .2972141 & .9230486 & -1.104606 & 2.129017 \\
\hline $\begin{array}{l}\text { Lag of the log of ratio of } \\
\text { FDI to GDP }\end{array}$ & 3344 & -.086772 & 1.659605 & -8.031686 & 4.978178 \\
\hline $\begin{array}{l}\text { Lag of the log of ratio of } \\
\text { Reserves in moths of } \\
\text { imports }\end{array}$ & 3687 & .8576736 & .9757717 & -6.114763 & 3.238615 \\
\hline $\begin{array}{l}\text { Lag of the log of real GDP } \\
\text { per capita }\end{array}$ & 2798 & 7.777605 & 1.55145 & 4.439352 & 10.8719 \\
\hline $\begin{array}{l}\text { Lag of the ratio of short } \\
\text { term debt to total debt (M) }\end{array}$ & 3429 & .1240123 & .128602 & 0 & .9990642 \\
\hline Polity 2 & 4102 & .4193077 & 7.567316 & -10 & 10 \\
\hline Crisis Episodes & 3039 & .1378743 & .3448247 & 0 & 1 \\
\hline
\end{tabular}




\begin{tabular}{|l|c|c|c|c|c|}
\hline $\begin{array}{l}\text { Output loss in the aftermath } \\
\text { of a crisis }\end{array}$ & 3039 & .0035077 & .0337175 & 0 & 1.08 \\
\hline
\end{tabular}

(A) The negative of the trade to GDP ratio over 100. Source: WDI-CD ROM

(B) See Appendix A.2 for an explanation of the methodology employed and data used.

(C) The ratio of foreign liabilities of the financial sector to money. Source: IFS (Line 26C/line 34)

(D) The ratio of "Total Dollar Deposits/Total Deposits. Source: Arteta (2002) and Arteta (2003)

(E) Source: IFS line 89c

(F) Ratio over 100. Source: WDI-CD ROM

(G) Ratio over 100. Source: IMF-IFS

$(\mathrm{H})$ inde $=1$ is (de-facto) flexible exchange rate; index $=2$ is (de-facto) intermediate arrangement; and inde $x=3$ is (de-facto) peg. Source: Levy Yeyati and Sturzenegger (2003).

(I) Source: Kaufman et. al. (2002)

(J) Source: WDI-CR ROM

(K) Source: WDI-CD ROM

(L) Source: WDI-CD ROM

(M) Ratio over 100. Source: WDI-CD Rom

(O) Range $=-10$ to 10 ( $-10=$ high autocracy; $10=$ high democracy). Combined Polity Score: Computed by subtracting AUTOC from DEMOC; normal range polity scores are imputed for coded "interregnum" and "transition period" special polity conditions, polities coded "interruption" on the POLITY variable are left blank. Source: Marshall and Jaggers (2002).

(P) Source: Frankel and Wei (2004). The approach in Frankel and Wei (2004) is to use the foreign exchange market pressure index. This index is defined as the percentage fall in reserves plus the percentage fall in the foreign exchange value of the currency. The idea is that this index measures the fall in demand for the country's currency; it is then up to the monetary authorities to determine whether to accommodate, by letting the money supply fall, or to depreciate. To avoid treating every year of a multi-year high-inflation period as a separate crisis, the approach followed by the authors requires that for an event to be considered a crisis episode, the increase in exchange market pressure must represent an acceleration of at least an additional 10 percent over the preceding period; and they also adopt an exclusion window of 3 years.

(Q) Source: Frankel and Wei (2004). 


\section{A.4. Summary Statistics tabulated by SS1}

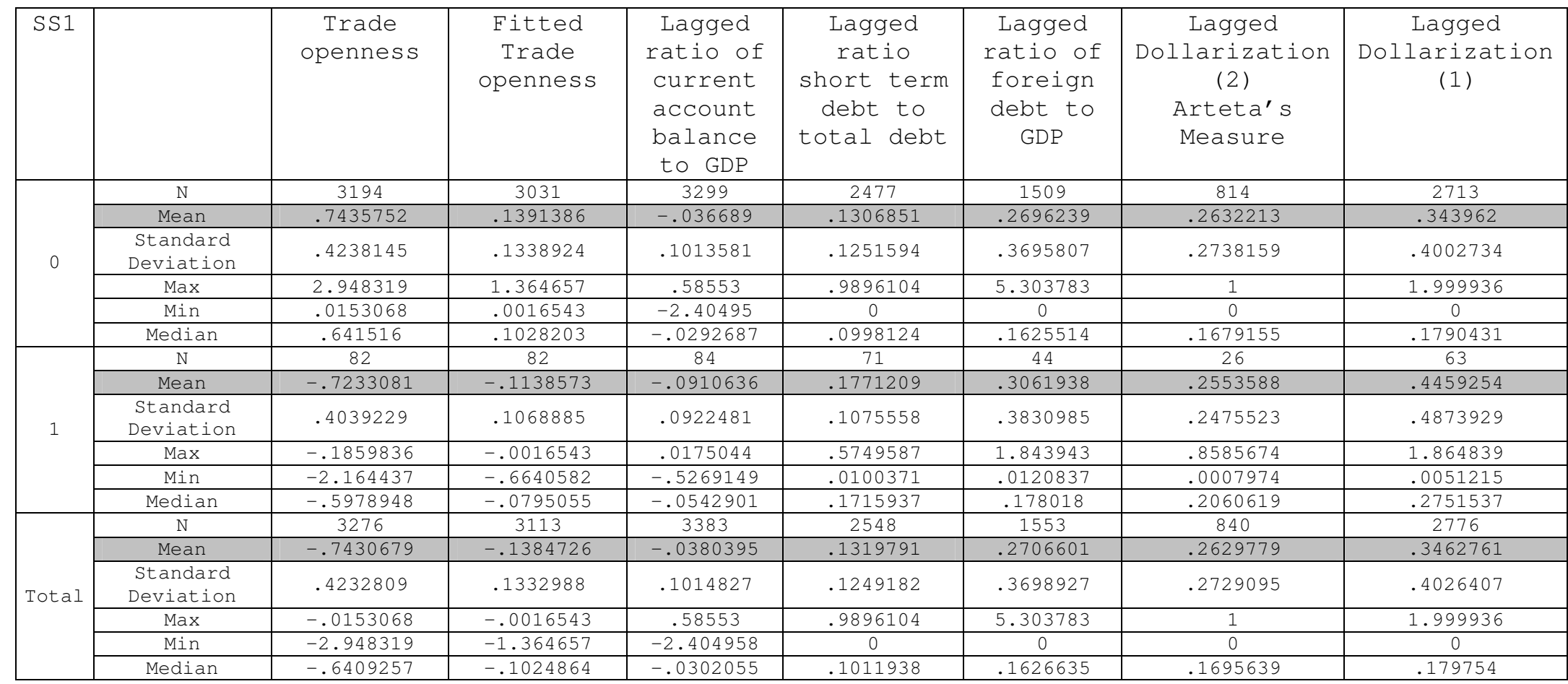




\begin{tabular}{|c|c|c|c|c|c|c|c|c|}
\hline SS 1 & & $\begin{array}{l}\text { Lagged } \\
\text { Index of } \\
\text { Exchange } \\
\text { Rate } \\
\text { Rigidity }\end{array}$ & $\begin{array}{c}\text { Voice and } \\
\text { Accountability }\end{array}$ & $\begin{array}{c}\text { Political } \\
\text { Stability/lack } \\
\text { of Violence }\end{array}$ & $\begin{array}{l}\text { Effectiveness } \\
\text { of Government }\end{array}$ & $\begin{array}{l}\text { Regulatory } \\
\text { Framework }\end{array}$ & $\begin{array}{l}\text { Rule of } \\
\text { Law }\end{array}$ & $\begin{array}{l}\text { Control of } \\
\text { Corruption }\end{array}$ \\
\hline \multirow{6}{*}{0} & $\mathrm{~N}$ & 2558 & 2508 & 2347 & 2347 & 2483 & 2483 & 2347 \\
\hline & Mean & 2.35731 & .3879369 & .2489824 & .3526585 & .3883469 & .3380581 & .3369313 \\
\hline & $\begin{array}{l}\text { Standard } \\
\text { Deviation }\end{array}$ & .8247772 & .9008189 & .8401079 & .86721 & .5761471 & .8931987 & .9569204 \\
\hline & Max & 3 & 1.693636 & 1.69047 & 2.082198 & 1.244778 & 1.995832 & 2.129017 \\
\hline & Min & 1 & -1.623367 & -1.694225 & -1.320767 & -1.500832 & -1.203638 & -1.104606 \\
\hline & Median & 3 & .4057957 & .164349 & .1734646 & .4442023 & .2741438 & .020012 \\
\hline \multirow{6}{*}{1} & $\mathrm{~N}$ & 66 & 69 & 67 & 67 & 69 & 69 & 67 \\
\hline & Mean & 2.333333 & .227192 & .0607287 & .2434398 & .4245789 & .2118273 & .1812266 \\
\hline & $\begin{array}{c}\text { Standard } \\
\text { Deviation }\end{array}$ & .8289629 & .8603037 & .80767 & .7970953 & .4912563 & .8233971 & .8957398 \\
\hline & $\operatorname{Max}$ & 3 & 1.628049 & 1.514361 & 2.030241 & 1.232713 & 1.824 & 2.085337 \\
\hline & Min & 1 & -1.357771 & -1.694225 & -1.320767 & -1.169838 & -1.203638 & -1.104606 \\
\hline & Median & 3 & .1533591 & .0833327 & .1636702 & .5331683 & .0391075 & -.1452185 \\
\hline \multirow{6}{*}{ Total } & $\mathrm{N}$ & 2624 & 2577 & 2414 & 2414 & 2552 & 2552 & 2414 \\
\hline & Mean & 2.356707 & .3836329 & .2437574 & .3496271 & .3893265 & .3346452 & .3326097 \\
\hline & $\begin{array}{c}\text { Standard } \\
\text { Deviation }\end{array}$ & .8247325 & .899972 & .839633 & .8653738 & .5739639 & .8914687 & .955443 \\
\hline & Max & 3 & 1.693636 & 1.69047 & 2.082198 & 1.244778 & 1.995832 & 2.129017 \\
\hline & Min & 1 & -1.623367 & -1.694225 & -1.320767 & -1.500832 & -1.203638 & -1.104606 \\
\hline & Median & 3 & .3913744 & .164349 & .1734646 & .4442023 & .2698059 & .020012 \\
\hline
\end{tabular}




\begin{tabular}{|c|c|c|c|c|c|c|c|c|c|c|c|c|}
\hline SS 1 & & $\begin{array}{c}\text { Polity } \\
2\end{array}$ & $\begin{array}{l}\text { Lag of } \\
\text { the log } \\
\text { ratio } \\
\text { of FDI } \\
\text { to GDP }\end{array}$ & $\begin{array}{l}\text { Lag of } \\
\text { the log } \\
\text { ratio of } \\
\text { Reserves } \\
\text { to Money }\end{array}$ & $\begin{array}{l}\text { Lag of } \\
\text { the log } \\
\text { of real } \\
\text { GDP per } \\
\text { capita }\end{array}$ & $\begin{array}{c}\text { Asia- } \\
\text { Pacific }\end{array}$ & Europe & $\begin{array}{c}\text { Latin } \\
\text { America } \\
\text { and the } \\
\text { Caribbean }\end{array}$ & $\begin{array}{c}\text { Middle } \\
\text { East }\end{array}$ & Africa & $\begin{array}{l}\text { South } \\
\text { Asia }\end{array}$ & $\begin{array}{c}\text { North } \\
\text { America }\end{array}$ \\
\hline \multirow{6}{*}{0} & $\mathrm{~N}$ & 2888 & 2739 & 3320 & 2307 & 3222 & 3222 & 3222 & 3222 & 3222 & 3222 & 3222 \\
\hline & Mean & 1.601801 & -.060504 & .858744 & 7.844113 & .129375 & .2071875 & .2453125 & .106875 & .2515625 & .04 & .0196875 \\
\hline & $\begin{array}{c}\text { Standard } \\
\text { Deviation }\end{array}$ & 7.589532 & 1.651816 & .9538479 & 1.558114 & .335667 & .4053544 & .4303396 & .3090025 & .4339789 & .1959898 & .1389458 \\
\hline & $\operatorname{Max}$ & 10 & 4.348825 & 3.238615 & 10.8719 & 1 & 1 & 1 & 1 & 1 & 1 & 1 \\
\hline & Min & -10 & $\begin{array}{c}- \\
7.811624\end{array}$ & -6.114763 & 4.439352 & 0 & 0 & 0 & 0 & 0 & 0 & 0 \\
\hline & Median & 5 & .1566815 & .9742805 & 7.625561 & 0 & 0 & 0 & 0 & 0 & 0 & 0 \\
\hline \multirow{6}{*}{1} & $\mathrm{~N}$ & 73 & 76 & 82 & 63 & 84 & 84 & 84 & 84 & 84 & 84 & 84 \\
\hline & Mean & 2.068493 & .2983586 & .8429953 & 7.703143 & .1585366 & .1341463 & .3292683 & .1463415 & .2073171 & .0121951 & .0121951 \\
\hline & $\begin{array}{c}\text { Standard } \\
\text { Deviation }\end{array}$ & 7.142068 & 1.764806 & .9447249 & 1.304005 & .3674911 & .3429068 & .4728395 & .3556233 & .4078793 & .1104315 & .1104315 \\
\hline & Max & 10 & 3.106559 & 2.355545 & 10.21361 & 1 & 1 & 1 & 1 & 1 & 1 & 1 \\
\hline & Min & -10 & -8.03168 & -2.404618 & 4.608365 & 0 & 0 & 0 & 0 & 0 & 0 & 0 \\
\hline & Median & 4 & .4463752 & 1.094091 & 7.794864 & 0 & 0 & 0 & 0 & 0 & 0 & 0 \\
\hline \multirow{6}{*}{ Total } & $\mathrm{N}$ & 2961 & 2815 & 3402 & 2370 & 3306 & 3306 & 3306 & 3306 & 3306 & 3306 & 3306 \\
\hline & Mean & 1.613306 & -.050816 & .8583644 & 7.840365 & .1301036 & .2053626 & .2474101 & .1078611 & .250457 & .0393053 & .0195003 \\
\hline & $\begin{array}{c}\text { Standard } \\
\text { Deviation }\end{array}$ & 7.578023 & 1.655657 & .9534944 & 1.55183 & .3364686 & .4040279 & .4315728 & .3102521 & .4333423 & .19435 & .1382963 \\
\hline & Max & 10 & 4.348825 & 3.238615 & 10.8719 & 1 & 1 & 1 & 1 & 1 & 1 & 1 \\
\hline & Min & -10 & $\begin{array}{c}- \\
8.031686\end{array}$ & -6.114763 & 4.439352 & 0 & 0 & 0 & 0 & 0 & 0 & 0 \\
\hline & Median & 5 & .1619896 & .9755991 & 7.632787 & 0 & 0 & 0 & 0 & 0 & 0 & 0 \\
\hline
\end{tabular}




\section{A.5. Robustness Check Tables}

\section{Table 5: Pooled OLS (Linear) Regressions}

\begin{tabular}{|c|c|c|c|c|c|c|c|c|c|}
\hline & \multicolumn{9}{|c|}{ Dependent Variable: Sudden Stop 1} \\
\hline Trade openness $t$ & $\begin{array}{c}\mathbf{- 0 . 0 2 4} \\
(0.013)^{*}\end{array}$ & $\begin{array}{c}\mathbf{- 0 . 0 3 8} \\
(0.019)^{* *}\end{array}$ & $\begin{array}{c}\mathbf{- 0 . 1 9 1} \\
(0.063)^{* *}\end{array}$ & $\begin{array}{c}\mathbf{- 0 . 0 2 1} \\
(0.0241)\end{array}$ & $\begin{array}{c}\mathbf{- 0 . 0 4 1} \\
(0.019)^{* *}\end{array}$ & $\begin{array}{c}\mathbf{- 0 . 0 3 0} \\
(0.0159)^{*}\end{array}$ & $\begin{array}{c}\mathbf{- 0 . 0 3 3} \\
(0.0179)^{*}\end{array}$ & $\begin{array}{c}\mathbf{- 0 . 0 3 5} \\
(0.017)^{* *}\end{array}$ & $\begin{array}{c}\mathbf{- 0 . 0 2 1} \\
(0.0137) \\
\end{array}$ \\
\hline $\begin{array}{l}\text { Foreign Debt/ } \\
\text { GDP }_{\text {t-1 }}\end{array}$ & $\begin{array}{c}\mathbf{- 0 . 0 0 9} \\
(0.0175) \\
\end{array}$ & $\begin{array}{c}\mathbf{- 0 . 0 0 8} \\
(0.0222) \\
\end{array}$ & $\begin{array}{c}\mathbf{0 . 1 0 0} \\
(0.130) \\
\end{array}$ & $\begin{array}{c}\mathbf{- 0 . 0 2 9} \\
(0.0193) \\
\end{array}$ & $\begin{array}{l}\mathbf{- 0 . 0 0 3} \\
(0.022) \\
\end{array}$ & $\begin{array}{c}\mathbf{- 0 . 0 1 3} \\
(0.0198) \\
\end{array}$ & $\begin{array}{c}\mathbf{- 0 . 0 0 9} \\
(0.0208) \\
\end{array}$ & $\begin{array}{l}\mathbf{- 0 . 0 0 9} \\
(0.021) \\
\end{array}$ & \\
\hline $\begin{array}{l}\text { Short Term Debt/ } \\
\text { Total Debt t-1 }\end{array}$ & & $\begin{array}{c}\mathbf{0 . 0 4 5} \\
(0.055)\end{array}$ & $\begin{array}{l}\mathbf{- 0 . 0 4 5} \\
(0.162)\end{array}$ & $\begin{array}{c}\mathbf{0 . 1 1 8 6} \\
(0.0974)\end{array}$ & $\begin{array}{c}\mathbf{0 . 0 6 7} \\
(0.0515)\end{array}$ & & $\begin{array}{c}\mathbf{0 . 0 3 5} \\
(0.0523)\end{array}$ & $\begin{array}{c}\mathbf{0 . 0 4 4} \\
(0.059)\end{array}$ & $\begin{array}{c}\mathbf{0 . 0 2 6} \\
(0.0393)\end{array}$ \\
\hline $\begin{array}{l}\text { Liability } \\
\text { Dollarization } t-1 \\
\text { (1) }\end{array}$ & $\begin{array}{c}\mathbf{0 . 0 2 2} \\
(0.017)\end{array}$ & $\begin{array}{c}\mathbf{0 . 0 2 3} \\
(0.030)\end{array}$ & & $\begin{array}{c}\mathbf{0 . 0 2 9} \\
(0.0346)\end{array}$ & & $\begin{array}{c}\mathbf{0 . 0 2 5} \\
(0.0189)\end{array}$ & $\begin{array}{c}\mathbf{0 . 0 2 5} \\
(0.0291)\end{array}$ & $\begin{array}{c}\mathbf{0 . 0 3 1} \\
(0.0298)\end{array}$ & $\begin{array}{c}\mathbf{0 . 0 3 1 2} \\
(0.0276)\end{array}$ \\
\hline $\begin{array}{l}\text { Liability } \\
\text { Dollarization } t-1 \\
\text { (2) }\end{array}$ & & & $\begin{array}{c}\mathbf{- 0 . 0 5 9} \\
(0.0944)\end{array}$ & & & & & & \\
\hline $\begin{array}{l}\text { Exchange Rate } \\
\text { Rigidity Index t-1 }\end{array}$ & & & & $\begin{array}{c}\mathbf{0 . 0 0 7} \\
(0.0113) \\
\end{array}$ & & & & & \\
\hline $\begin{array}{l}\text { Current Account/ } \\
\text { GDP }_{\text {t-1 }}\end{array}$ & $\begin{array}{c}\mathbf{- 0 . 2 2} \\
(0.072)^{* *}\end{array}$ & $\begin{array}{c}\mathbf{- 0 . 2 6 5} \\
(0.105)^{* *} \\
\end{array}$ & $\begin{array}{c}\mathbf{- 0 . 6 6 1} \\
(0.298)^{* *} \\
\end{array}$ & $\begin{array}{c}\mathbf{- 0 . 3 4 3} \\
(0.139)^{* *} \\
\end{array}$ & $\begin{array}{c}\mathbf{- 0 . 2 7 4} \\
(0.103)^{* *} \\
\end{array}$ & $\begin{array}{c}\mathbf{- 0 . 2 3 5} \\
(0.088)^{* *} \\
\end{array}$ & $\begin{array}{r}\mathbf{- 0 . 2 7 5} \\
(0.095)^{* *} \\
\end{array}$ & $\begin{array}{c}\mathbf{- 0 . 2 6 1} \\
(0.099)^{* *}\end{array}$ & $\begin{array}{c}\mathbf{- 0 . 1 7 0} \\
(0.065)^{* *}\end{array}$ \\
\hline FDI/GDP $_{t-1}$ & & & & $\begin{array}{l}\mathbf{- 0 . 0 0 0 9} \\
(0.0019) \\
\end{array}$ & & & & & \\
\hline $\begin{array}{l}\text { Ln Reserves in } \\
\text { Months of } \\
\text { Imports t-1 }\end{array}$ & & & & $\begin{array}{c}\text { 0.0008 } \\
(0.0033)\end{array}$ & & & & & \\
\hline $\begin{array}{l}\text { Ln GDP } \\
\text { per capita }{ }_{t-1}\end{array}$ & & $\begin{array}{c}\mathbf{0 . 0 0 3} \\
(0.0135)\end{array}$ & $\begin{array}{c}\mathbf{0 . 0 8 2} \\
(0.0444)^{*}\end{array}$ & $\begin{array}{c}\mathbf{- 0 . 0 0 8} \\
(0.0138) \\
\end{array}$ & $\begin{array}{c}\mathbf{0 . 0 0 5} \\
(0.0125) \\
\end{array}$ & $\begin{array}{c}\mathbf{- 0 . 0 0 6} \\
(0.0086) \\
\end{array}$ & $\begin{array}{c}\mathbf{0 . 0 0 5} \\
(0.0111) \\
\end{array}$ & & $\begin{array}{c}\mathbf{0 . 0 1 0} \\
(0.0099)\end{array}$ \\
\hline $\begin{array}{l}\text { Effectiveness of } \\
\text { Government } t\end{array}$ & & $\begin{array}{c}\mathbf{0 . 0 0 4 6} \\
(0.0215) \\
\end{array}$ & $\begin{array}{c}\mathbf{- 0 . 0 7 0} \\
(0.0401)^{*}\end{array}$ & $\begin{array}{c}\mathbf{0 . 0 1 4 6} \\
(0.0247) \\
\end{array}$ & $\begin{array}{c}\mathbf{0 . 0 0 7} \\
(0.0192)\end{array}$ & $\begin{array}{c}\mathbf{- 0 . 0 0 2} \\
(0.0182) \\
\end{array}$ & & $\begin{array}{c}\mathbf{0 . 0 0 5} \\
(0.0179) \\
\end{array}$ & $\begin{array}{c}\mathbf{0 . 0 0 3} \\
(0.0139) \\
\end{array}$ \\
\hline $\begin{array}{c}\text { Regional } \\
\text { Dummies? }\end{array}$ & YES & YES & YES & YES & YES & YES & YES & YES & YES \\
\hline $\begin{array}{l}\text { Year Fixed- } \\
\text { Effects? }\end{array}$ & YES & YES & YES & YES & YES & YES & YES & YES & YES \\
\hline Constant & $\begin{array}{c}\mathbf{- 0 . 0 0 1 3} \\
(0.014) \\
\end{array}$ & $\begin{array}{c}\mathbf{- 0 . 0 0 4} \\
(0.0965) \\
\end{array}$ & $\begin{array}{c}\mathbf{- 0 . 2 7 7} \\
(0.3261) \\
\end{array}$ & $\begin{array}{c}\mathbf{0 . 0 8 4} \\
(0.1177) \\
\end{array}$ & $\begin{array}{c}\mathbf{0 . 0 0 0 7} \\
(0.1076) \\
\end{array}$ & $\begin{array}{c}\mathbf{0 . 0 6 1} \\
(0.0758) \\
\end{array}$ & $\begin{array}{c}\mathbf{- 0 . 0 0 0 5} \\
(0.1033) \\
\end{array}$ & $\begin{array}{c}\mathbf{0 . 0 1 4} \\
(0.033) \\
\end{array}$ & $\begin{array}{c}\mathbf{- 0 . 0 8 1} \\
(0.0788) \\
\end{array}$ \\
\hline Obs. & 1122 & 745 & 219 & 599 & 787 & 961 & 869 & 772 & 1235 \\
\hline $\mathbf{R}^{2}$ & 0.0416 & 0.0573 & 0.1903 & 0.0745 & $\mathbf{0 . 0 5 5 0}$ & 0.0500 & 0.0512 & 0.0550 & 0.0373 \\
\hline
\end{tabular}

Robust standard error to clustered heterogeneity reported in parenthesis.

*** Statistically Significant at $1 \%$

** Statistically Significant at 5\%

* Statistically Significant at $10 \%$ 
Table 6: Instrumental Variables Linear Regressions

\begin{tabular}{|c|c|c|c|c|c|c|c|c|c|}
\hline & \multicolumn{9}{|c|}{ Dependent Variable: Sudden Stop 1} \\
\hline Trade openness t & $\begin{array}{c}\mathbf{- 0 . 0 6 6} \\
(0.02)^{* * *} \\
\end{array}$ & $\begin{array}{c}\mathbf{- 0 . 0 9 3} \\
(0.057)^{* *} \\
\end{array}$ & $\begin{array}{c}\mathbf{- 0 . 2 3 3} \\
(0.101)^{* *} \\
\end{array}$ & $\begin{array}{c}\mathbf{- 0 . 1 3 3} \\
(0.064)^{* *} \\
\end{array}$ & $\begin{array}{c}\mathbf{- 0 . 1 0 0} \\
(0.03)^{* * *}\end{array}$ & $\begin{array}{c}\mathbf{- 0 . 0 6 3} \\
(0.02)^{* *} \\
\end{array}$ & $\begin{array}{c}\mathbf{- 0 . 0 9 7} \\
(0.032)^{* *} \\
\end{array}$ & $\begin{array}{c}\mathbf{- 0 . 0 8 8} \\
(0.03)^{* *} \\
\end{array}$ & $\begin{array}{c}\mathbf{- 0 . 0 6 0} \\
(0.02)^{* *} \\
\end{array}$ \\
\hline $\begin{array}{l}\text { Foreign Debt/ } \\
\text { GDP }_{\text {t-1 }}\end{array}$ & $\begin{array}{c}\mathbf{- 0 . 0 0 6} \\
(0.0182) \\
\end{array}$ & $\begin{array}{c}\mathbf{0 . 0 0 7} \\
(0.0239) \\
\end{array}$ & $\begin{array}{c}\mathbf{0 . 1 0 8} \\
(0.1408) \\
\end{array}$ & $\begin{array}{l}\mathbf{- 0 . 0 0 0 2} \\
(0.0255) \\
\end{array}$ & $\begin{array}{c}\mathbf{0 . 0 1 2} \\
(0.024) \\
\end{array}$ & $\begin{array}{c}\mathbf{- 0 . 0 0 7} \\
(0.0201) \\
\end{array}$ & $\begin{array}{c}\mathbf{0 . 0 0 8} \\
(0.0222) \\
\end{array}$ & $\begin{array}{c}\mathbf{0 . 0 0 4} \\
(0.0223) \\
\end{array}$ & \\
\hline $\begin{array}{l}\text { Short Term Debt/ } \\
\text { Total Debt } t-1\end{array}$ & & $\begin{array}{c}\mathbf{0 . 0 7 1} \\
(0.0595)\end{array}$ & $\begin{array}{c}\mathbf{- 0 . 0 2 3} \\
(0.1705)\end{array}$ & $\begin{array}{c}\mathbf{0 . 1 2 8} \\
(0.1076)\end{array}$ & $\begin{array}{c}\mathbf{0 . 0 8 8} \\
(0.0537)^{*}\end{array}$ & & $\begin{array}{c}\mathbf{0 . 0 6 5} \\
(0.0559)\end{array}$ & $\begin{array}{c}\mathbf{0 . 0 8 2} \\
(0.0687)\end{array}$ & $\begin{array}{c}\mathbf{0 . 0 2 5} \\
(0.0399)\end{array}$ \\
\hline $\begin{array}{l}\text { Liability } \\
\text { Dollarization t-1 } \\
\text { (1) }\end{array}$ & $\begin{array}{c}\mathbf{0 . 0 2 7} \\
(0.0169)\end{array}$ & $\begin{array}{c}\mathbf{0 . 0 1 6} \\
(0.0315)\end{array}$ & & $\begin{array}{c}\mathbf{0 . 0 2 8} \\
(0.0334)\end{array}$ & & $\begin{array}{c}\mathbf{0 . 0 2 9} \\
(0.0190)\end{array}$ & $\begin{array}{c}\mathbf{0 . 0 1 5} \\
(0.0274)\end{array}$ & $\begin{array}{c}\mathbf{0 . 0 2 4} \\
(0.0313)\end{array}$ & $\begin{array}{c}\mathbf{0 . 0 2 8} \\
(0.0284)\end{array}$ \\
\hline $\begin{array}{l}\text { Liability } \\
\text { Dollarization } t-1 \\
(2)\end{array}$ & & & $\begin{array}{c}\mathbf{- 0 . 0 7 3} \\
(0.1082)\end{array}$ & & & & & & \\
\hline $\begin{array}{l}\text { Exchange Rate } \\
\text { Rigidity Index t-1 }\end{array}$ & & & & $\begin{array}{c}\mathbf{0 . 0 1 1} \\
(0.0119) \\
\end{array}$ & & & & & \\
\hline $\begin{array}{l}\text { Current Account/ } \\
\text { GDP }_{\text {t-1 }}\end{array}$ & $\begin{array}{c}\mathbf{- 0 . 3 1 7} \\
(0.10)^{* * *}\end{array}$ & $\begin{array}{c}\mathbf{- 0 . 3 8 0} \\
(0.145)^{* *}\end{array}$ & $\begin{array}{c}\mathbf{- 0 . 6 6 5} \\
(0.290)^{* *}\end{array}$ & $\begin{array}{c}\mathbf{- 0 . 4 7 5} \\
(0.192)^{* *}\end{array}$ & $\begin{array}{c}\mathbf{- 0 . 3 9 5} \\
(0.1427)^{* *}\end{array}$ & $\begin{array}{c}\mathbf{- 0 . 3 2 3} \\
(0.116)^{* *}\end{array}$ & $\begin{array}{c}\mathbf{- 0 . 3 6 4} \\
(0.123)^{* *}\end{array}$ & $\begin{array}{c}\mathbf{- 0 . 3 6 1} \\
(0.131)^{* *}\end{array}$ & $\begin{array}{c}\mathbf{- 0 . 2 3 0} \\
(0.084)^{* *}\end{array}$ \\
\hline FDI/GDP ${ }_{t-1}$ & & & & $\begin{array}{l}\mathbf{- 0 . 0 0 0 3} \\
(0.0032) \\
\end{array}$ & & & & & \\
\hline $\begin{array}{l}\text { Ln Reserves in } \\
\text { Months of } \\
\text { Imports t-1 }\end{array}$ & & & & $\begin{array}{l}\mathbf{- 0 . 0 0 1 4} \\
(0.0036)\end{array}$ & & & & & \\
\hline $\begin{array}{l}\text { Ln GDP } \\
\text { per capita } t-1\end{array}$ & & $\begin{array}{c}\mathbf{0 . 0 0 9} \\
(0.0146) \\
\end{array}$ & $\begin{array}{c}\mathbf{0 . 0 8 6} \\
(0.0443) \\
\end{array}$ & $\begin{array}{c}\mathbf{- 0 . 0 0 5} \\
(0.0157) \\
\end{array}$ & $\begin{array}{c}\mathbf{0 . 0 1 1 2} \\
(0.0135) \\
\end{array}$ & $\begin{array}{c}\mathbf{- 0 . 0 0 4} \\
(0.0088) \\
\end{array}$ & $\begin{array}{c}\mathbf{0 . 0 1 5} \\
(0.0126) \\
\end{array}$ & & $\begin{array}{c}\mathbf{0 . 0 1 4} \\
(0.0110) \\
\end{array}$ \\
\hline $\begin{array}{l}\text { Effectiveness of } \\
\text { Government } t\end{array}$ & & $\begin{array}{c}\mathbf{0 . 0 0 7} \\
(0.0221)\end{array}$ & $\begin{array}{l}\mathbf{- 0 . 0 7 2} \\
(0.041)^{*}\end{array}$ & $\begin{array}{c}\mathbf{0 . 0 2 1} \\
(0.0255)\end{array}$ & $\begin{array}{c}\mathbf{0 . 0 0 7} \\
(0.0194)\end{array}$ & $\begin{array}{l}\mathbf{- 0 . 0 0 6 1} \\
(0.0187)\end{array}$ & & $\begin{array}{c}\mathbf{0 . 0 1 1} \\
(0.0192) \\
\end{array}$ & $\begin{array}{c}\mathbf{0 . 0 0 7} \\
(0.0148) \\
\end{array}$ \\
\hline $\begin{array}{c}\text { Regional } \\
\text { Dummies? }\end{array}$ & YES & YES & YES & YES & YES & YES & YES & YES & YES \\
\hline $\begin{array}{l}\text { Year Fixed- } \\
\text { Effects? }\end{array}$ & YES & YES & YES & YES & YES & YES & YES & YES & YES \\
\hline Constant & \begin{tabular}{|l|}
$\mathbf{0 . 0 3 6 3 3}$ \\
$(0.027)$ \\
\end{tabular} & $\begin{array}{c}\mathbf{- 0 . 0 2} \\
(0.1055) \\
\end{array}$ & $\begin{array}{c}-\mathbf{- 0 . 3 1 2} \\
(0.337) \\
\end{array}$ & $\begin{array}{c}\mathbf{0 . 0 5 5} \\
(0.0911) \\
\end{array}$ & $\begin{array}{c}\mathbf{0 . 0 4 9} \\
(0.1178) \\
\end{array}$ & $\begin{array}{c}\mathbf{0 . 0 8 5} \\
(0.0791) \\
\end{array}$ & $\begin{array}{c}\mathbf{0 . 0 1 5 8} \\
(0.1192) \\
\end{array}$ & $\begin{array}{c}\mathbf{0 . 0 9 2} \\
(0.0557)^{*}\end{array}$ & $\begin{array}{c}\mathbf{- 0 . 0 6 3} \\
(0.0842) \\
\end{array}$ \\
\hline Obs. & 1040 & 705 & 215 & 559 & 747 & 914 & 800 & 731 & 1176 \\
\hline $\mathbf{R}^{2}$ & 0.0421 & 0.0571 & 0.1923 & 0.0769 & 0.0548 & 0.0508 & 0.0491 & 0.0546 & 0.0337 \\
\hline
\end{tabular}

Robust standard errors reported in parenthesis.

*** Statistically Significant at $1 \%$

** Statistically Significant at 5\%

* Statistically Significant at 10\% 
Table 7: Instrumental Variables GLS Random-Effects Regressions

\begin{tabular}{|c|c|c|c|c|c|c|c|c|c|}
\hline & \multicolumn{9}{|c|}{ Dependent Variable: Sudden Stop 1} \\
\hline Trade openness $t$ & $\begin{array}{c}\mathbf{- 0 . 0 6 6} \\
(0.026)^{* *} \\
\end{array}$ & $\begin{array}{c}\mathbf{- 0 . 0 9 4} \\
(0.0417)^{* *}\end{array}$ & $\begin{array}{c}\mathbf{- 0 . 2 3 3} \\
(0.138)^{*}\end{array}$ & $\begin{array}{c}\mathbf{- 0 . 1 0 5} \\
(0.0437)^{* *}\end{array}$ & $\begin{array}{c}\mathbf{- 0 . 1 0 0} \\
(0.0387)^{* *}\end{array}$ & $\begin{array}{c}\mathbf{- 0 . 0 6 9} \\
(0.0344)^{* *}\end{array}$ & $\begin{array}{c}\mathbf{- 0 . 1 0 5} \\
(0.0423)^{* *}\end{array}$ & $\begin{array}{c}\mathbf{- 0 . 0 8 8} \\
(0.040)^{* *} * \\
\end{array}$ & $\begin{array}{c}\mathbf{- 0 . 0 6 0} \\
(0.0302)^{* *}\end{array}$ \\
\hline $\begin{array}{l}\text { Foreign Debt/ } \\
\text { GDP }_{t-1}\end{array}$ & $\begin{array}{c}\mathbf{- 0 . 0 0 6} \\
(0.0155) \\
\end{array}$ & $\begin{array}{c}\mathbf{0 . 0 0 7} \\
(0.0235) \\
\end{array}$ & $\begin{array}{c}\mathbf{0 . 1 0 8} \\
(0.0945) \\
\end{array}$ & $\begin{array}{c}\mathbf{0 . 0 0 8} \\
(0.0235) \\
\end{array}$ & $\begin{array}{c}\mathbf{0 . 0 1 2} \\
(0.0223) \\
\end{array}$ & $\begin{array}{c}\mathbf{- 0 . 0 0 3} \\
(0.0188) \\
\end{array}$ & $\begin{array}{c}\mathbf{0 . 0 1 2} \\
(0.0223) \\
\end{array}$ & $\begin{array}{c}\mathbf{0 . 0 0 4} \\
(0.0219) \\
\end{array}$ & \\
\hline $\begin{array}{l}\text { Short Term Debt/ } \\
\text { Total Debt }{ }_{\text {t-1 }}\end{array}$ & & $\begin{array}{c}\mathbf{0 . 0 7 1} \\
(0.0692)\end{array}$ & $\begin{array}{c}\mathbf{- 0 . 0 2 3} \\
(0.1807)\end{array}$ & $\begin{array}{c}\mathbf{0 . 0 6 3} \\
(0.0704)\end{array}$ & $\begin{array}{c}\mathbf{0 . 0 8 8} \\
(0.0632)\end{array}$ & & $\begin{array}{c}\mathbf{0 . 0 6 6} \\
(0.0633)\end{array}$ & $\begin{array}{c}\mathbf{0 . 0 8 2} \\
(0.0647)\end{array}$ & $\begin{array}{c}\mathbf{0 . 0 2 5} \\
(0.0486)\end{array}$ \\
\hline $\begin{array}{l}\text { Liability } \\
\text { Dollarization } t-1 \\
\text { (1) }\end{array}$ & $\begin{array}{c}\mathbf{0 . 0 2 7} \\
(0.0149)^{*}\end{array}$ & $\begin{array}{c}\mathbf{0 . 0 1 6} \\
(0.0251)\end{array}$ & & $\begin{array}{c}\mathbf{0 . 0 1 5} \\
(0.0251)\end{array}$ & & $\begin{array}{c}\mathbf{0 . 0 2 9} \\
(0.0168)^{*}\end{array}$ & $\begin{array}{c}\mathbf{0 . 0 1 4} \\
(0.0234)\end{array}$ & $\begin{array}{c}\mathbf{0 . 0 2 4} \\
(0.0247)\end{array}$ & $\begin{array}{c}\mathbf{0 . 0 2 8} \\
(0.0192)\end{array}$ \\
\hline $\begin{array}{l}\text { Liability } \\
\text { Dollarization t-1 } \\
\text { (2) }\end{array}$ & & & $\begin{array}{c}\mathbf{- 0 . 0 7 3} \\
(0.0875)\end{array}$ & & & & & & \\
\hline $\begin{array}{l}\text { Exchange Rate } \\
\text { Rigidity Index t-1 }\end{array}$ & & & & $\begin{array}{c}\mathbf{0 . 0 1 1} \\
(0.013)\end{array}$ & & & & & \\
\hline $\begin{array}{l}\text { Current Account/ } \\
\text { GDP }_{\text {t-1 }}\end{array}$ & $\begin{array}{c}\mathbf{- 0 . 3 1 7} \\
(0.095)^{* * *}\end{array}$ & $\begin{array}{c}\mathbf{- 0 . 3 8 0} \\
(0.1325)^{* *}\end{array}$ & $\begin{array}{c}\mathbf{- 0 . 6 6 5} \\
(0.3354)^{* *}\end{array}$ & $\begin{array}{c}\mathbf{- 0 . 4 1 3} \\
(0.142)^{* *} \\
\end{array}$ & $\begin{array}{c}\mathbf{- 0 . 3 9 5} \\
(0.129)^{* *} \\
\end{array}$ & $\begin{array}{c}\mathbf{- 0 . 3 4 0} \\
(0.1085)^{* *}\end{array}$ & $\begin{array}{c}\mathbf{- 0 . 3 8 2} \\
(0.119)^{* * *}\end{array}$ & $\begin{array}{c}\mathbf{- 0 . 3 6 1} \\
(0.1275)^{* *}\end{array}$ & $\begin{array}{c}\mathbf{- 0 . 2 3 0} \\
(0.0888)^{* *}\end{array}$ \\
\hline FDI/GDP t-1 & & & & $\begin{array}{c}\mathbf{0 . 0 0 0 7} \\
(0.0033) \\
\end{array}$ & & & & & \\
\hline $\begin{array}{l}\text { Ln Reserves in } \\
\text { Months of } \\
\text { Imports }_{t-1}\end{array}$ & & & & $\begin{array}{c}\mathbf{0 . 0 0 3} \\
(0.0030)\end{array}$ & & & & & \\
\hline $\begin{array}{l}\text { Ln GDP } \\
\text { per capita }_{t-1}\end{array}$ & & $\begin{array}{c}\mathbf{0 . 0 0 9} \\
(0.0148) \\
\end{array}$ & $\begin{array}{c}\mathbf{0 . 0 8 6} \\
(0.0468)^{*} \\
\end{array}$ & $\begin{array}{c}\mathbf{0 . 0 0 9} \\
(0.0148) \\
\end{array}$ & $\begin{array}{c}\mathbf{0 . 0 1 1} \\
(0.0141) \\
\end{array}$ & $\begin{array}{c}\mathbf{- 0 . 0 0 3} \\
(0.0094) \\
\end{array}$ & $\begin{array}{c}\mathbf{0 . 0 1 6 7} \\
(0.0141) \\
\end{array}$ & & $\begin{array}{c}\mathbf{0 . 0 1 4} \\
(0.0102) \\
\end{array}$ \\
\hline $\begin{array}{l}\text { Effectiveness of } \\
\text { Government } t_{t}\end{array}$ & & $\begin{array}{c}\mathbf{0 . 0 0 7} \\
(0.0186) \\
\end{array}$ & $\begin{array}{c}\mathbf{- 0 . 0 7 2} \\
(0.0417)^{*}\end{array}$ & $\begin{array}{c}\mathbf{0 . 0 0 6} \\
(0.0187) \\
\end{array}$ & $\begin{array}{c}\mathbf{0 . 0 0 7} \\
(0.0172)\end{array}$ & $\begin{array}{l}\mathbf{- 0 . 0 0 8} \\
(0.015)\end{array}$ & & $\begin{array}{c}\mathbf{0 . 0 1 1} \\
(0.0166)\end{array}$ & $\begin{array}{c}\mathbf{0 . 0 0 7} \\
(0.0123) \\
\end{array}$ \\
\hline $\begin{array}{c}\text { Regional } \\
\text { Dummies? }\end{array}$ & YES & YES & YES & YES & YES & YES & YES & YES & YES \\
\hline $\begin{array}{l}\text { Year Fixed- } \\
\text { Effects? }\end{array}$ & YES & YES & YES & YES & YES & YES & YES & YES & YES \\
\hline Constant & $\begin{array}{c}\mathbf{0 . 0 2 4} \\
(0.0999)\end{array}$ & $\begin{array}{c}\mathbf{0 . 0 6 4} \\
(0.1748)\end{array}$ & $\begin{array}{l}\mathbf{- 0 . 3 1 2} \\
(0.338)\end{array}$ & $\begin{array}{c}\mathbf{0 . 0 0 1} \\
(0.1786)\end{array}$ & $\begin{array}{c}\mathbf{0 . 0 5 0} \\
(0.1701)\end{array}$ & $\begin{array}{c}\mathbf{0 . 0 7 8} \\
(0.1274)\end{array}$ & $\begin{array}{c}\mathbf{- 0 . 0 2 9} \\
(0.1505)\end{array}$ & $\begin{array}{c}\mathbf{0 . 0 9 2} \\
(0.1440)\end{array}$ & $\begin{array}{c}\mathbf{- 0 . 0 8 3} \\
(0.1124)\end{array}$ \\
\hline Obs. & 1040 & 705 & 215 & 705 & 747 & 914 & 800 & 731 & 1176 \\
\hline $\mathbf{R}^{2}$ & 0.0435 & 0.0583 & 0.1931 & 0.0576 & 0.0564 & 0.0503 & 0.0499 & 0.0557 & 0.0345 \\
\hline
\end{tabular}

Standard errors reported in parenthesis.

*** Statistically Significant at $1 \%$

** Statistically Significant at 5\%

* Statistically Significant at 10\% 
Table 8: Output Loss Regressions

\begin{tabular}{|c|c|c|c|c|}
\hline & Non-IV Tobit & IV-Tobit & IV-Linear & IV-Probit \\
\hline & \multicolumn{4}{|c|}{ Dependent Variable: Output loss in the event of a crisis [Frankel and Wei (2004)] } \\
\hline Trade openness $_{t}$ & $\begin{array}{c}\mathbf{- 0 . 3 7} \\
(0.179) * *\end{array}$ & $\begin{array}{c}\mathbf{- 0 . 3 1} \\
(0.357)\end{array}$ & $\begin{array}{l}\mathbf{- 0 . 0 0 7} \\
(0.006)\end{array}$ & $\begin{array}{c}\mathbf{- 1 . 9 3} \\
(1.097)^{*}\end{array}$ \\
\hline Foreign Debt/GDP ${ }_{t-1}$ & $\begin{array}{c}\mathbf{0 . 1 4} \\
(0.089) \\
\end{array}$ & $\begin{array}{c}\mathbf{0 . 2 0} \\
(0.109)^{*}\end{array}$ & $\begin{array}{c}\mathbf{0 . 0 0 6} \\
(0.007) \\
\end{array}$ & $\begin{array}{c}\mathbf{0 . 9 2} \\
(0.356)^{* *} \\
\end{array}$ \\
\hline $\begin{array}{l}\text { Liability } \\
\text { Dollarization } t-1 \\
\text { (1) }\end{array}$ & $\begin{array}{c}\mathbf{0 . 2 1} \\
(0.118)^{*}\end{array}$ & $\begin{array}{c}\mathbf{0 . 0 7 6} \\
(0.104)\end{array}$ & $\begin{array}{c}\mathbf{0 . 0 0 4} \\
(0.005)\end{array}$ & $\begin{array}{c}\mathbf{0 . 5 7} \\
(0.276)^{* *}\end{array}$ \\
\hline $\begin{array}{l}\text { Ln Reserves in } \\
\text { Months of Imports }{ }_{t-1}\end{array}$ & $\begin{array}{c}\mathbf{- 0 . 0 8 2} \\
(0.044)^{*}\end{array}$ & $\begin{array}{c}\mathbf{- 0 . 1 0 8} \\
(0.045)^{*}\end{array}$ & $\begin{array}{r}\mathbf{- 0 . 0 0 2} \\
(0.002)\end{array}$ & $\begin{array}{c}\mathbf{- 0 . 3 4} \\
(0.130)^{* *}\end{array}$ \\
\hline $\begin{array}{l}\text { Short Term Debt/ } \\
\text { Total Debt }{ }_{t-1}\end{array}$ & $\begin{array}{c}\mathbf{0 . 7 0} \\
(0.349)^{* *} \\
\end{array}$ & $\begin{array}{c}\mathbf{0 . 6 4} \\
(0.346)^{* *} \\
\end{array}$ & $\begin{array}{c}\mathbf{0 . 0 0 8} \\
(0.019) \\
\end{array}$ & \\
\hline Regional Dummies? & YES & NO & YES & NO \\
\hline Year Fixed-Effects? & NO & NO & YES & YES \\
\hline Constant & $\begin{array}{c}\mathbf{- 0 . 9 2} \\
(0.270)^{* * *}\end{array}$ & $\begin{array}{c}\mathbf{- 0 . 7 2} \\
(0.255)^{* *}\end{array}$ & $\begin{array}{c}\mathbf{0 . 0 0 2} \\
(0.0099) \\
\end{array}$ & $\begin{array}{l}\mathbf{- 0 . 0 2 6} \\
(0.867)\end{array}$ \\
\hline Obs. & 750 & 868 & 729 & 1081 \\
\hline $\mathbf{R}^{2}$ & 0.1791 & $\mathbf{n} / \mathbf{a}$ & 0.04902 & $\mathbf{n} / \mathbf{a}$ \\
\hline
\end{tabular}

Standard errors reported in parenthesis.

*** Statistically Significant at $1 \%$

** Statistically Significant at 5\%

* Statistically Significant at 10\% 